\title{
Economic Contributions of Agriculture, Natural Resources, and Related Food Industries in Florida in $2011^{1}$
}

\author{
Alan W. Hodges, Mohammad Rahmani, and Thomas J. Stevens ${ }^{2}$ \\ To access the complete report, go to http://edis.ifas.ufl.edu/pdffiles/FE/FE93500.pdf
}

\section{Executive Summary}

Agriculture, natural resources, and related food industries remain a significant force in the economy of Florida, and it is important to recognize their economic contributions for informed public policy. We evaluated the economic contributions of these industries for calendar year 2011 to update previous reports and provide further information on economic trends in the wake of the historic global recession of 20072009.

This analysis was conducted using the IMPLAN regional economic modeling system (MIG, Inc.) and associated state and county databases to estimate economic multipliers that capture the additional economic activity generated by the re-spending of income in the local economy arising from extra new final demand. The industry sectors included in this analysis represent a broad array of activities for agricultural and natural resource commodity production, distribution, and supporting services. The extent of the total effects of a particular activity or event in a region (state, county) is measured by several yardsticks, including employment, output, value added, export, labor income, other property income, and indirect business taxes. Value-added is a preferred measure of economic activity because it is comparable to Gross Domestic Product (GDP). The glossary of economic impact terms that follows this summary will orient the reader to technical terms used in this report.

\footnotetext{
${ }^{1}$ This is EDIS document FE935, a publication of the Food and Resource Economics Department, Florida Cooperative Extension Service, Institute of Food and Agricultural Sciences, University of Florida, Gainesville, FL 32611. Published June 2013. Please visit the EDIS website at http://edis.ifas.ufl.edu/.

2 Alan W. Hodges, extension scientist; Mohammad Rahmani, economic analyst; and Thomas J. Stevens, postdoctoral research associate, Food and Resource Economics Department, University of Florida, Gainesville, FL.
} 
Economic contribution results for Florida's agriculture, natural resources, and related food industries for 2011 included:

- Industry output or sales revenues of $\$ 130.37$ billion, and total output contribution of $\$ 198.90$ billion, including indirect/induced multiplier effects arising from foreign and domestic exports of $\$ 47.45$ billion

- Total employment impacts (including multiplier effects) of 1.96 million full-time and part-time jobs, representing 20.2 percent of all jobs in the state

- Direct value-added of $\$ 62.63$ billion, representing 8.5 percent of Florida's GDP, and total valueadded impacts (including multiplier effects) of $\$ 104.30$ billion, representing 14.2 percent of state GDP.

- Total labor income impacts of $\$ 67.52$ billion for employee wages and benefits and business proprietor income, and total property income impacts of $\$ 24.96$ billion for rents, interest, royalties and dividends

- Total indirect business-tax impacts of $\$ 11.82$ billion paid to local, state, and federal governments

Across the various groups of agriculture, natural resource, and related food industry sectors, total employment and value added impacts were largest for the Food and Kindred Products Distribution industry group (1.18 million jobs; $\$ 56.36$ billion), which includes food service establishments (restaurants and bars) and retail food stores, followed by Agricultural Inputs and Services (292,142 jobs; $\$ 13.29$ billion); Crop, Livestock, Forestry, and Fisheries Production (220,839 jobs; \$11.64 billion); Food and Kindred Product Manufacturing (137,339 jobs; \$13.4 billion); Forest Product Manufacturing (62,929 jobs; \$5.31 billion); Mining (56,966 jobs; \$3.69 billion); and Nature-Based Recreation (11,296 jobs; \$626 million). Excluding the Food and Kindred Products Distribution industry group, total value-added impacts represented 6.52 percent of state GDP and employment was 8.02 percent of total state employment.

Information on economic contributions was also regrouped and evaluated for several agricultural commodities that have identifiable market-chain linkages between production and processing/manufacturing sectors. The total employment and value-added contributions were highest for the Environmental Horticulture group (221,063 jobs; $\$ 9.72$ billion), followed by Fruit and Vegetable Farming and Processing (94,698 jobs; $\$ 7.36$ billion); Agricultural Input and Services (138,965 jobs; $\$ 7.04$ billion); Forestry and Forest Products (75,704 jobs; \$6.01 billion); Sugarcane Farming and Refined Sugar Manufacturing (29,303 jobs; \$1.15 billion); Livestock and Dairy Farming and Animal Products Manufacturing (23,296 jobs; \$1.14 billion); Grain \& Oilseed Farming \& Processing (3,073 jobs; \$291 million); and Fishing and Seafood Products (9,518 jobs; \$260 million). 
Geographically, the size and composition of agriculture, natural resources, and related food industries varies dramatically across the state of Florida due to differences in climate, natural resource endowments, population, and settlement patterns. The largest economic contributions occurred in the major metro areas of Miami-Ft. Lauderdale, Orlando, Tampa-St. Petersburg, Sarasota-Bradenton, and Jacksonville, where there are large demands for food and kindred products and a large workforce available for the industry. The eight largest counties in terms of total employment and value-added impacts were Miami-Dade (222,402 jobs; $\$ 13.20$ billion); Hillsborough (148,158 jobs; $\$ 9.27$ billion); Orange (155,653 jobs; $\$ 8.31$ billion); Palm Beach (148,994 jobs; $\$ 8.20$ billion); Broward (159,638 jobs; $\$ 8.03$ billion); Duval (110,550 jobs; $\$ 7.91$ billion); Polk (93,237 jobs; $\$ 6.10$ billion); and Pinellas (87,981 jobs; $\$ 4.32$ billion). However, the economic contributions of agriculture and related industries are also relatively more important in many rural areas, where these industries represent a higher share of total economic activity, in some cases up to 80 percent. Additional detailed information on economic contributions in individual Florida counties is available at http://www.fred.ifas.ufl.edu/economic-impact-analysis/Florida-countyprofiles-2011.pdf.

Direct employment in the agriculture, natural resources, and related food industries in Florida grew from 1.281 million jobs in 2001 to a peak of 1.403 million jobs in 2008 , before declining to 1.331 million jobs in 2009 during the recession. In 2011, direct employment increased again to 1.408 million jobs, which was 9.9 percent higher than in 2001, representing average annual growth of 0.8 percent; and total employment impacts increased to 1.965 million jobs, reflecting a dramatic increase in exports of Florida products to domestic and world markets. Average annual growth in value-added impacts during 20012011 was highest for Mining (8.3\%), followed by Agricultural Inputs and Services (5.4\%) and Food and Kindred Products Distribution (4.1\%). Growth rates in agriculture and related industries were higher than in many other Florida industries during the recent period. 
Table ES1. Summary of economic contributions of agriculture, natural resources, and related food industries in Florida in 2011, by major industry group and Florida region

\begin{tabular}{|c|c|c|c|c|c|c|c|c|}
\hline Industry Group & $\begin{array}{l}\text { Direct } \\
\text { Employ- } \\
\text { ment } \\
\text { (Jobs) }\end{array}$ & $\begin{array}{c}\text { Direct } \\
\text { Output } \\
(\mathrm{M} \$)\end{array}$ & $\begin{array}{l}\text { Exports } \\
(\mathrm{M} \$)\end{array}$ & $\begin{array}{c}\text { Employ- } \\
\text { ment } \\
\text { Impacts } \\
\text { (Jobs) }\end{array}$ & $\begin{array}{l}\text { Value- } \\
\text { Added } \\
\text { Impacts } \\
(\mathrm{M} \$)\end{array}$ & $\begin{array}{l}\text { Labor } \\
\text { Income } \\
\text { Impacts } \\
(\mathrm{M} \$)\end{array}$ & $\begin{array}{c}\text { Other } \\
\text { Property } \\
\text { Income } \\
\text { Impacts } \\
(\mathrm{M} \$)\end{array}$ & $\begin{array}{c}\text { Indirect } \\
\text { Business } \\
\text { Tax } \\
\text { Impacts } \\
\text { (M\$) }\end{array}$ \\
\hline $\begin{array}{l}\text { Crop, Livestock, Forestry } \\
\text { \& Fisheries Production }\end{array}$ & 130,546 & 10,537 & 6,595 & 220,839 & 11,639 & 7,856 & 3,314 & 470 \\
\hline $\begin{array}{l}\text { Agricultural Inputs \& } \\
\text { Services }\end{array}$ & 201,261 & 17,036 & 9,318 & 292,142 & 13,287 & 9,455 & 3,048 & 785 \\
\hline $\begin{array}{l}\text { Food \& Kindred Products } \\
\text { Manufacturing }\end{array}$ & 40,204 & 23,252 & 10,642 & 137,339 & 13,396 & 6,863 & 4,581 & 1,951 \\
\hline $\begin{array}{l}\text { Forest Products } \\
\quad \text { Manufacturing }\end{array}$ & 18,444 & 6,924 & 4,650 & 62,929 & 5,306 & 3,345 & 1,624 & 337 \\
\hline $\begin{array}{l}\text { Food \& Kindred Products } \\
\text { Distribution }\end{array}$ & 989,278 & 67,147 & 12,989 & $1,183,709$ & 56,358 & 37,518 & 10,870 & 7,970 \\
\hline Mining & 20,425 & 4,908 & 3,027 & 56,966 & 3,686 & 2,105 & 1,342 & 239 \\
\hline Nature-Based Recreation & 7,762 & 568 & 226 & 11,296 & 626 & 375 & 179 & 72 \\
\hline \multicolumn{9}{|l|}{ Florida Region } \\
\hline Miami-Fort Lauderdale & 467,894 & 41,374 & 17,259 & 641,007 & 34,825 & 23,117 & 7,927 & 3,686 \\
\hline Orlando & 347,135 & 31,910 & 15,064 & 489,440 & 25,047 & 16,254 & 6,054 & 3,093 \\
\hline Tampa-St. Petersburg & 192,799 & 19,063 & 8,429 & 273,410 & 15,041 & 9,955 & 3,356 & 1,606 \\
\hline Sarasota-Bradenton & 147,569 & 11,304 & 4,613 & 199,048 & 9,634 & 6,614 & 2,074 & 886 \\
\hline Jacksonville & 104,450 & 13,291 & 7,478 & 161,615 & 10,756 & 6,029 & 3,091 & 1,631 \\
\hline Gainesville & 40,312 & 3,785 & 2,016 & 53,112 & 2,221 & 1,311 & 676 & 218 \\
\hline Tallahassee & 33,522 & 3,603 & 2,069 & 48,526 & 2,395 & 1,526 & 628 & 225 \\
\hline Panama City & 23,364 & 2,103 & 1,106 & 34,103 & 1,557 & 952 & 433 & 165 \\
\hline Pensacola & 49,256 & 3,769 & 1,510 & 64,959 & 2,822 & 1,757 & 721 & 313 \\
\hline $\begin{array}{l}\text { Total All Industries, } \\
\text { All Regions }\end{array}$ & $1,406,301$ & 130,203 & 59,543 & $1,965,221$ & 104,299 & 67,516 & 24,959 & 11,823 \\
\hline
\end{tabular}

Total impact estimates include regional multiplier effects. Employment represents full-time and part-time positions. Source: IMPLAN data for Florida (MIG, Inc.). 


\section{Glossary of Economic Impact Terms}

Apparent consumption represents the consumption of any particular commodity in a region. It is calculated as the local output plus imports minus exports.

Contribution (economic) represents the gross change in economic activity associated with an industry, event, or policy in an existing regional economy.

Employee compensation is comprised of wages, salaries, commissions, and benefits such as health and life insurance, retirement, and other forms of cash or non-cash compensation.

Employment is a measure of the number of jobs involved, including full-time, part-time, and temporary/seasonal positions. It is not a measure of full-time equivalents (FTE).

Exports are sales of goods to customers outside the region in which they are produced, which represents a net inflow of money to the region. This also applies to sales of services to customers visiting from other regions.

Final demand represents sales to final consumers, including households and governments, and exports from the region.

Gross regional product is a measure of total economic activity in a region, or total income generated by all goods and services. It represents the sum of total value added by all industries in that region, and is equivalent to GDP for the nation.

IMPLAN is a computer-based input-output modeling system that enables users to create regional economic models and multipliers for any region consisting of one or more counties or states in the United States. The current version of the IMPLAN software, version 3, accounts for commodity production and consumption for 440 industry sectors, 10 household income levels, taxes to local/state/federal governments, capital investment, imports and exports, transfer payments, and business inventories. Regional datasets for individual counties or states are purchased separately.

Impact or total impact is the change in total regional economic activity (e.g., output or employment) resulting from a change in final demand, direct industry output, or direct employment, estimated based on regional economic multipliers.

Imports are purchases of goods and services originating outside the region of analysis.

Income is the money earned within the region from production and sales. Total income includes labor income such as wages, salaries, employee benefits, and business proprietor income, plus other property income. 
Indirect business taxes are taxes paid to governments by individuals or businesses for property, excise, and sales taxes, but do not include income taxes.

Input-Output (I-O) model and Social Accounting Matrix (SAM) represent the transactions between industry sectors within a region and capture what each sector purchases from every other sector in order to produce its output of goods or services. The I-O model and SAM are a useful way to understand an economy by tracking changes in spending through the supply chain.

Intermediate sales are sales to other industrial sectors. The value of intermediate sales is netted out of (subtracted from) total value added.

Local refers to goods and services that are sourced from within the region, which may be defined as a county, multi-county cluster, or state. Non-local refers to economic activity originating outside the region.

Margins represent the portion of the purchaser price accruing to the retailer, wholesaler, and producer/manufacturer in the supply chain. Typically, only the retail margins of many goods purchased by consumers accrue to the local region because the wholesaler, shipper, and manufacturer often lie outside the local area.

Multipliers capture the total effects, both direct and secondary, in a given region, generally as a ratio of the total change in economic activity in the region relative to the direct change. Multipliers are derived from an I-O model of the regional economy. Multipliers may be expressed as ratios of sales, income, or employment, or as ratios of total income or employment changes relative to direct sales. Multipliers express the degree of interdependency between sectors in a region's economy and therefore vary considerably across regions and sectors. A sector-specific multiplier gives the total changes to the economy associated with a unit change in output or employment in a given sector (i.e., the direct economic effect) being evaluated. Indirect effects multipliers represent the changes in sales, income, or employment within the region in backward-linked industries supplying goods and services to businesses (e.g., increased sales in input supply firms resulting from more nursery industry sales). Induced effects multipliers represent the increased sales within the region from household spending of the income earned in the direct and supporting industries for housing, utilities, food, etc. An imputed multiplier is calculated as the ratio of the total impact divided by direct effect for any given measure (e.g., output, employment).

Other property income represents income received from investments such as corporate dividends, royalties, property rentals, or interest on loans.

Output is the dollar value of a good or service produced or sold, and is equivalent to sales revenues plus changes in business inventories. 
Output-consumption ratio is the total industry output divided by the apparent consumption for any given commodity or industry, and is a measure of the degree to which local demands are met by local production.

Producer prices are the prices paid for goods at the factory or point of production. For manufactured goods, the purchaser price equals the producer price plus a retail margin, a wholesale margin, and a transportation margin. For services, the producer and purchaser prices are equivalent.

Proprietor income is income received by non-incorporated private business owners or self-employed individuals.

Purchaser prices are the prices paid by the final consumer of a good or service.

Region defines the geographic area for which impacts are estimated, usually an aggregation of several counties defined on the basis of worker commuting patterns.

Sector is an individual industry or group of industries that produce similar products or services or that have similar production processes. Sectors are classified according to the North American Industrial Classification System (NAICS).

Value-added is a broad measure of income representing the sum of employee compensation, proprietor income, other property income, indirect business taxes, and capital consumption (depreciation). Value added avoids double counting of intermediate sales and is therefore a commonly used measure of the contribution of an industry to the regional economy. 


\section{Introduction}

Agriculture, natural resources, and related food industries represent a major set of economic activities in terms of generating employment and income and producing goods and services that contribute to economic growth and development of Florida and the United States. These industries use natural resources provided by Florida's 24 million acres (36,000 square miles) of forests, croplands, and ranches to produce basic food, fiber, and mineral commodities. The unrefined commodities are converted into finished products by the food and kindred product manufacturing industries, and finished goods then move through the wholesale and retail distribution chain to final consumers or to other industry sectors as intermediate goods for further value-added processing. These industries are also linked to a broad array of allied suppliers that provide production inputs and supporting services. In addition, natural landscapes and other undeveloped lands provide an array of opportunities for nature-based recreation and eco-tourism. Thus, the chain of agricultural and related food industry activities encompasses "from farm to table" and beyond.

Economic impact analysis assesses the effect of a new or present activity, industry, or event on the overall economy of a region such as a state, county, or city. Any activity that generates payments has an effect on other parts of the local economy, and any expenditure by one person or entity becomes income to another entity. As an analogy, consider the waves generated from a stone thrown into a lake that spread out in all directions. In economic impact analysis, these are called secondary effects and are measured through economic multipliers for each type of activity (industry sector) obtained from regional economic models Assessment of the economic contributions of industries to the economy of Florida is important to making informed public policy decisions regarding future economic and community development, job creation, environmental regulation, labor and human resources, and taxation, among other issues. This report provides estimates of the economic contributions to the state of Florida in 2011 by a set of broadly defined industries comprising agriculture, natural resources, and related food activities. It updates and continues a series of annual studies done previously for 2006-2010 (Hodges, Rahmani, and Stevens 2011; Hodges and Rahmani 2010, 2009; Hodges, Rahmani, and Mulkey 2008).

\section{Methods}

Data for this analysis were obtained from the IMPLAN database for the state of Florida and its counties for 2001-2011 (MIG, Inc.), which in turn were derived from the National Income and Product Accounts for the United States (U.S. Department of Commerce, Bureau of Economic Analysis), the Quarterly Census of Employment and Wages (U.S. Bureau of Labor Statistics), and other sources. Over 90 individual industry sectors in the IMPLAN system were identified as related to agriculture and natural 
resource commodity production, input supply and supporting services, food and kindred product manufacturing, forest product manufacturing, food and kindred product distribution, and nature-based recreation. A complete list of industry groups and individual sectors included in the analysis is shown in Table 1. Note that some industry sectors in this analysis were reclassified from their original major industry group designation under the North American Industry Classification System (NAICS) to be included as part of the broadly defined agriculture and food-related industries. The rationale for including processing or manufacturing industries in this analysis is that they share a common dependence upon the natural resource base, and would not exist in the state if not for the basic production activities. Food and kindred product distribution sectors, such as wholesalers, food stores, and restaurants, although not strictly dependent upon Florida's agricultural production and natural resources, were also included in the analysis because they are the endpoint of the market chain for the delivery of agricultural and food products to final consumers.

Economic contribution information was also re-grouped for several recognizable commodity groups that have linkages between agricultural production and processing/manufacturing sectors. These included environmental horticulture (nursery and greenhouse production, landscape services, retail garden centers); fruit and vegetable farming/processing; forestry/logging/forest product manufacturing; sugarcane/refined sugar manufacturing; livestock/animal products manufacturing; and fishing/seafood products.

The total regional economic impacts for each sector were estimated using models developed with the IMPLAN software for social accounting and impact analysis (MIG, Inc.). This system enables construction of input-output models and social accounting matrices that represent the structure of a regional economy in terms of transactions among industry sectors, households, and governments. Regional economic models were developed for the state of Florida and for all 67 counties in the state using the IMPLAN software and associated Florida state/county data for 2011 (MIG, Inc.). Models were constructed with econometrically estimated regional purchase coefficients representing the share of commodities purchased from local sources; social/institutional accounts for households, local/state/federal governments, and capital investment were treated as endogenous within the models.

The IMPLAN model includes accounts for industrial and commodity production, employment, labor and property income, household and institutional consumption, domestic and international trade (imports, exports), government taxes, transfer payments such as welfare and retirement, and capital investment. Economic multipliers are calculated for each industry to estimate the secondary effects of new demand that generates further economic activity as it is re-spent in the local economy (Miller and Blair 2009). Indirect effects multipliers represent the economic activity generated in the supply chain through the purchase of intermediate inputs from vendor firms, while induced effects multipliers represent the impacts 
of spending by industry employee households and governments. The indirect and induced multipliers were applied only to foreign and domestic exports, or sales to visitors from outside the state of Florida, which represent new money flowing into the regional economy. The total economic impacts were calculated as the sum of direct, indirect, and induced effects. Therefore, while the estimates of this analysis are referred to as "economic impacts," these values may be better understood as "economic contributions" because they represent the ongoing economic activity of existing industries rather than a net change in activity resulting from external influences (Watson et al. 2007).

Measures of economic impacts reported here include output or revenue; value added; employment (including full-time, part-time, and temporary/seasonal positions); labor income; property income; and indirect business taxes paid to local, state, and federal governments. Value added is a broad measure of net economic activity that is comparable to the Gross Domestic Product (GDP) and represents the sum of labor and other property income, indirect business taxes, and capital consumption (depreciation). Note that industry output includes some double-counting of sales from one level of the market chain to the next (e.g., sales of citrus juice products by processors includes the value of citrus fruit purchased from growers), while value added does not have such double-counting because the value of intermediate inputs purchased from other sectors is netted-out (see Glossary of Economic Impact Terms).

Summary information was developed for the state of Florida, all 67 counties, and 9 multi-county regions. These functional economic areas represent core metropolitan areas and adjacent nonmetropolitan counties linked by employee commuting patterns, as defined by the U.S. Bureau of Economic Analysis (Johnson and Kort 2004). It should be noted that some Georgia counties included in the north Florida regions were not evaluated in this analysis. Due to differences in trade flows and accounting adjustments at the state and county levels, slight discrepancies in regional results were reconciled by forcing county and regional estimates to match with state totals.

For some activities that were not specifically identified in IMPLAN, values were estimated as a share of their parent sector based on data from the 2007 Economic Census and previous special studies: Landscape services and Pest control services were 49 percent and 15 percent, respectively, of Services to buildings; Wholesale food distribution was 20 percent of Wholesale trade; Retail lawn-and-garden centers were 19 percent of Building materials and garden stores; Golf courses and Recreational fishing were 48 percent and 10 percent, respectively, of Amusement and recreation services.

Reported employment figures represent all full-time, part-time, and temporary/seasonal jobs, rather than full-time equivalent employees. All monetary values were expressed in 2011 U.S. dollars using the midyear (July) indices for the 
GDP Implicit Price Deflator, which accounts for price changes in the measurement of GDP (U.S. Department of Commerce). Note that IMPLAN data were unavailable for 2005. Also, note that results for 2001 to 2010 were revised in light of new information, so findings presented here do not necessarily match those previously reported (Hodges, Rahmani, and Stevens 2011; Hodges and Rahmani 2010, 2009; Hodges, Rahmani, and Mulkey 2008).

\section{Results}

\section{Economic Contributions by Industry Groups and Sectors}

Economic contributions by major industry groups and individual industry sectors in Florida for 2011 are shown in Table 1 and summarized in Figures 1 to 3. The industries are categorized in seven major groups: Crop, Livestock, Forestry, and Fisheries Production; Agricultural Inputs and Services; Food and Kindred Products Manufacturing; Forest Products Manufacturing; Mining; Nature-based Recreation; and Food and Kindred Products Distribution. Results are reported below for each major group, each sector within the groups, all groups combined, and for all groups, excluding Food and Kindred Products Distribution. Direct industry output or sales revenues in 2011 were $\$ 130.37$ billion. Foreign and domestic exports of goods and services outside of Florida totaled $\$ 47.45$ billion. As a result of the indirect and induced multiplier effects arising from exports, an additional $\$ 68.53$ billion in output was generated in the economy, mostly in other economic sectors, giving total output impacts estimated at $\$ 198.90$ billion. Direct employment in these industries was 1.407 million full-time and part-time jobs, and total employment impacts (including multiplier effects) were estimated at 1.965 million jobs. The direct valueadded impacts of these industries were $\$ 62.63$ billion, and total value-added impacts were $\$ 104.30$ billion. The total labor (earned) income impacts of employee wages and benefits and business proprietor income were $\$ 67.52$ billion. Total property income impacts, such as rents, interest, royalties, and dividends, amounted to $\$ 24.96$ billion. Total indirect business-tax impacts paid to local, state, and federal governments were $\$ 11.82$ billion (Table 1). 
Figure 1. Structure of economic activity in agriculture, natural resources, and related food industries in Florida in 2011

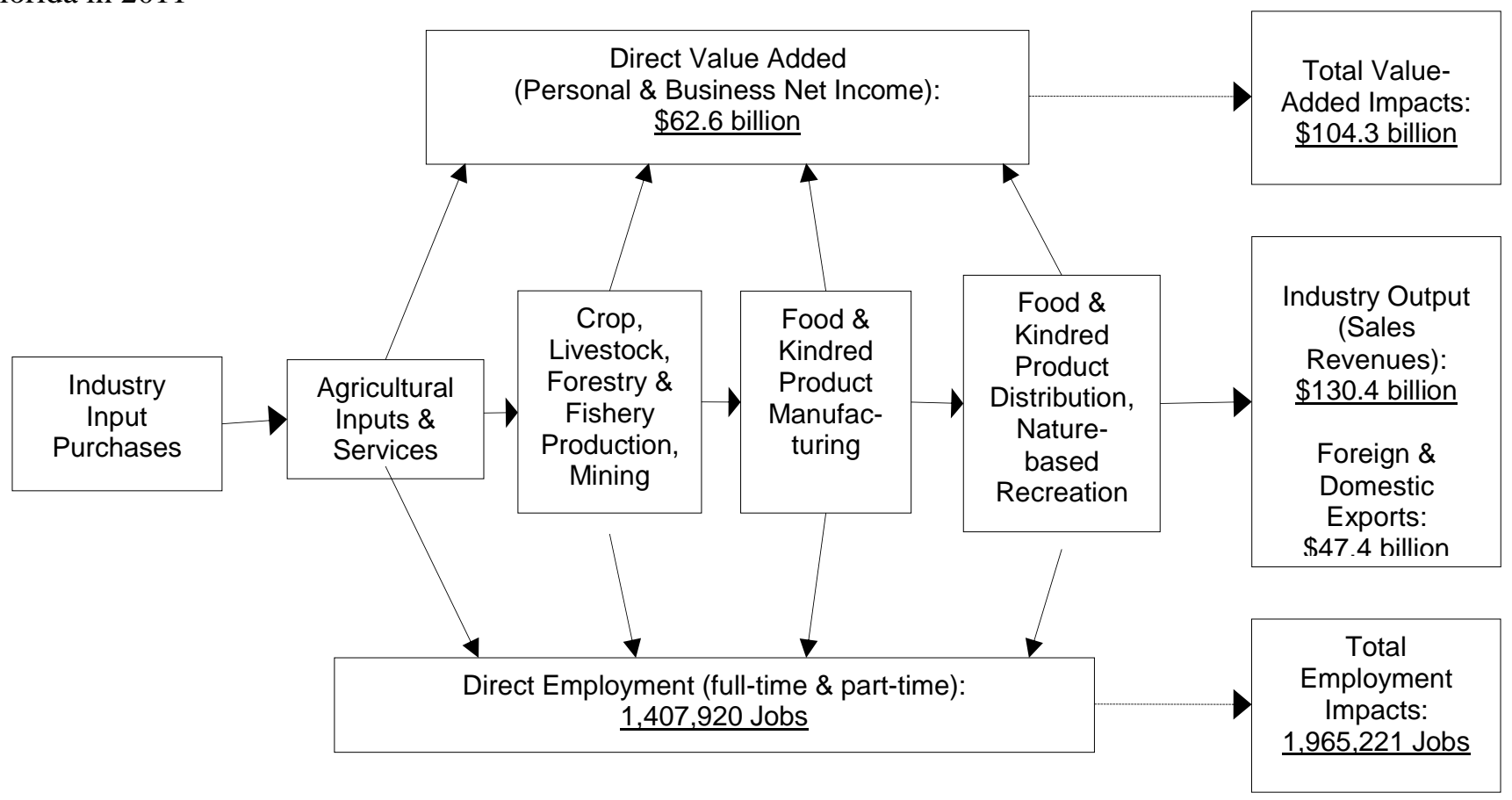

Values in 2011 U.S. dollars

Figure 2. Output and value-added contributions of agriculture, natural resources, and related food industry groups in Florida in 2011

Food \& Kindred Products Distribution

Food \& Kindred Products Manufacturing

Agricultural Inputs \& Services

Crop, Livestock, Forestry \& Fisheries Production

Forest Products Manufacturing

$$
\text { Mining }
$$

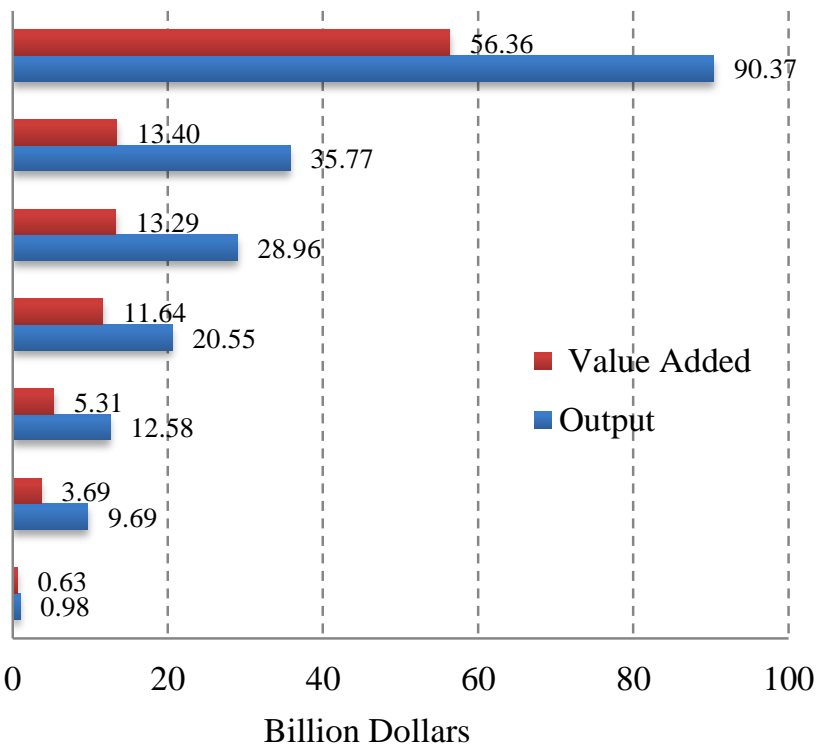

Source: IMPLAN data for Florida (MIG, Inc.). Estimates include regional multiplier effects. 
Figure 3. Employment contributions of agriculture, natural resources, and related food industry groups in Florida in 2011

Food \& Kindred Products Distribution

Agricultural Inputs \& Services

Crop, Livestock, Forestry \& Fisheries Production

Food \& Kindred Products Manufacturing

Forest Products Manufacturing Mining
Nature-based Recreation

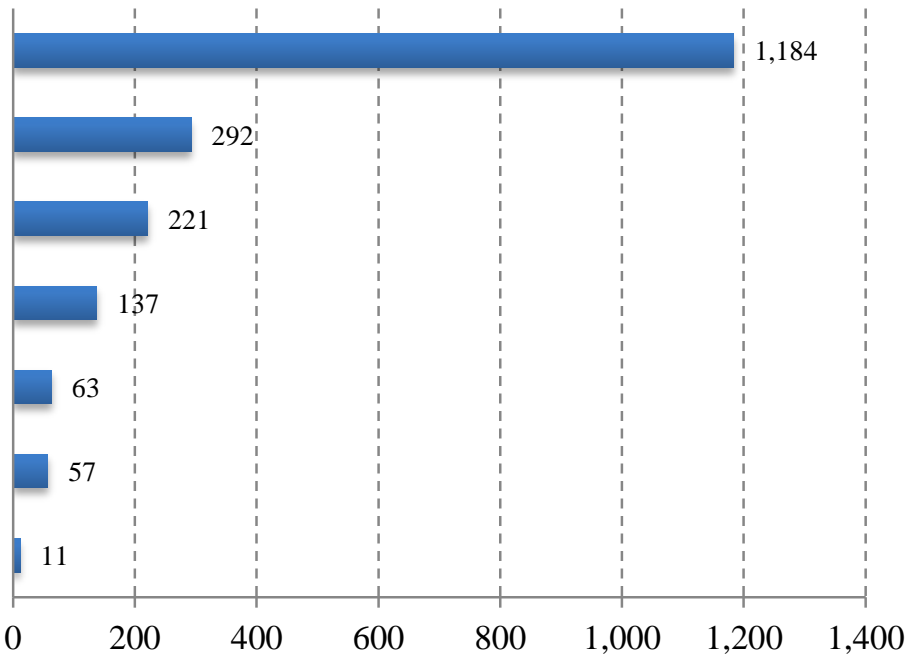

Full-time and Part-time Jobs (thousands)

Source: IMPLAN data for Florida (MIG, Inc.). Estimates include regional multiplier effects.

Crop, Livestock, Forestry, and Fisheries Production includes sectors for the production of basic unrefined food and fiber commodities. In 2011, total output of these sectors was $\$ 10.54$ billion, exports were $\$ 6.59$ billion, and output impacts were $\$ 20.55$ billion (Table 1, Figures 2 to 3 ). Direct value added was $\$ 5.44$ billion and total value-added impacts were $\$ 11.64$ billion. Direct employment was 130,546 jobs, and total employment impacts were 220,839 jobs (Figure 3). Labor income impacts were $\$ 7.86$ billion, other property-income impacts were $\$ 3.31$ billion, and indirect business-tax impacts were $\$ 470$ million. Among individual industry sectors in this group, the highest value-added impacts were for Fruit Farming (\$2.68 billion); Greenhouse, nursery, and floriculture production (\$2.54 billion); Vegetable and melon farming ( $\$ 2.16$ billion); Support activities for agriculture and forestry (1.90 billion); and Sugarcane farming (\$514 million). The highest employment impacts were for Support activities for agriculture and forestry (63,360 jobs); Fruit Farming (36,777 jobs); Greenhouse, nursery, and floriculture production (33,129 jobs); Vegetable and melon farming (27,279 jobs); and Sugarcane farming (18,628 jobs). Large value-added and employment impacts were also generated by the sectors Forestry and timber tracts (\$592 million; 9,419 jobs); Commercial fishing (\$178 million; 7,981 jobs); Dairy cattle and milk production (\$230 million; 4,774 jobs); and Cattle ranching and farming (\$223 million; 6,374 jobs). In addition, value-added impacts of more than $\$ 100$ million were observed for All other crop farming, Poultry and egg production, and Commercial logging. 
Agricultural Inputs and Services includes a variety of sectors providing inputs or supporting services for agricultural operations or landscape management. Output impacts in 2011 by this industry group totaled $\$ 28.96$ billion, including exports of $\$ 9.32$ billion (Table 1, Figures 2 to 3). Direct value added was $\$ 6.41$ billion and value-added impacts were $\$ 13.29$ billion. Direct employment was 201,261 jobs and employment impacts were 292,142 jobs (Figure 3). Labor income impacts were $\$ 9.45$ billion, other property-income impacts were $\$ 3.05$ billion, and indirect business-tax impacts were $\$ 785$ million. Among the leading sectors in this group, Landscape services had value-added impacts of $\$ 6.73$ billion and employment impacts of 178,799 jobs, followed by Fertilizer manufacturing ( $\$ 3.85$ billion; 44,777 jobs); Pest control services ( $\$ 1.42$ billion; 37,738 jobs); and Veterinary services ( $\$ 1.09$ billion; 29,163 jobs). Other minor sectors in this group included Pesticide and other agricultural chemical manufacturing, Farm machinery and equipment manufacturing, and Lawn and garden equipment manufacturing.

Food and Kindred Products Manufacturing is a large industry group that includes 33 individual sectors for converting unrefined agricultural commodities into food products for final consumption or use. In 2011 , this industry group had direct output of $\$ 23.25$ billion, exports of $\$ 10.64$ billion, and output impacts of $\$ 35.77$ billion. Direct employment was 40,204 jobs and total employment impacts were 137,339 jobs. The industry group had direct value added of $\$ 6.02$ billion, value-added impacts of $\$ 13.40$ billion, labor income impacts of $\$ 6.86$ billion, other property-income impacts of $\$ 4.58$ billion, and indirect business-tax impacts of $\$ 1.95$ billion (Table 1, Figures 2 to 3). Among individual sectors, the highest value-added and employment impacts were for Soft drink and ice manufacturing ( $\$ 2.74$ billion; 33,298 jobs); Tobacco product manufacturing ( $\$ 3.20$ billion; 13,098 jobs); Fruit and vegetable canning, pickling, and drying ( $\$ 1.58$ billion; 18,394 jobs); Breweries ( $\$ 1.06$ billion; 9,109 jobs); Frozen Food Manufacturing (\$932 million; 11,964 jobs); Sugarcane mills and refining (\$638 million; 10,675 jobs); and Distilleries (\$653 million; 5,418 jobs). Other sectors with significant value-added impacts included Bread and bakery product manufacturing (\$362 million); Other animal food manufacturing (\$314 million); All other food manufacturing (\$283 million); Fluid milk and butter manufacturing (\$227 million); Flour milling and malt manufacturing (\$226 million); Coffee and tea manufacturing (\$160 million); and Snack food manufacturing (\$127 million).

Forest Products Manufacturing is a group of industries for processing of raw timber or wood into finished wood and paper products. In 2011, this industry group had direct output valued at $\$ 6.92$ billion; exports of $\$ 4.65$ billion; output impacts of $\$ 12.58$ billion; direct employment of 18,444 jobs; employment impacts of 62,929 jobs; direct value added of $\$ 1.93$ billion; value-added impacts of $\$ 5.31$ billion; labor income impacts of $\$ 3.34$ billion; other property-income impacts of $\$ 1.62$ billion; and indirect business-tax impacts of $\$ 337$ million (Table 1, Figures 2 to 3). Leading sectors within this group in terms of value- 
added and employment impacts were Paperboard container manufacturing ( $\$ 952$ million; 11,882 jobs); Paper mills (\$951 million; 10,170 jobs); Sanitary paper products manufacturing (\$938 million; 8,090 jobs); Paperboard mills (\$711 million; 7,822 jobs); Pulp mills (\$670 million; 7,778 jobs); and Stationary product manufacturing (\$252 million; 3,243 jobs). Other sectors with significant value-added impacts included Coated and laminated paper packaging paper and plastics film manufacturing (\$143 million); Sawmills and wood preservation (\$134 million); Wood window and door manufacturing (\$127 million); and Engineered wood member and truss manufacturing (\$118 million).

Mining is a natural-resource-based activity for the extraction of basic mineral commodities such as oil, natural gas, stone, sand, gravel, clay, phosphate, and a variety of metals. In 2011, the mining industries in Florida collectively had direct output of $\$ 4.91$ billion; exports of $\$ 3.03$ billion; output impacts of $\$ 9.69$ billion; direct employment of 20,425 jobs; employment impacts of 56,966 jobs; direct value added of $\$ 740$ million; value-added impacts of $\$ 3.69$ billion; labor income impacts of $\$ 2.10$ billion; other propertyincome impacts of $\$ 1.34$ billion; and indirect business-tax impacts of $\$ 239$ million (Table 1, Figures 2 to 3). The largest individual sector was Extraction of oil and natural gas, which generated value-added impacts of $\$ 2.08$ billion and employment impacts of 39,094 jobs. Other individual sectors with significant value-added and employment impacts included Mining and quarrying of other nonmetallic minerals (\$598 million; 5,981 jobs); Mining and quarrying stone (\$386 million; 4,204 jobs); Mining and quarrying of sand, gravel, and clay (\$264 million; 3,328 jobs); and Drilling of oil and gas wells (\$170 million; 2,064 jobs). Other minor sectors in this industry group were Support activities for oil and gas operations; Mining gold, silver and other metal ore; and Support activities for other mining.

Nature-Based Recreation includes recreational activities generally tied to natural resources or managed landscapes such as golf, recreational fishing, and hunting and trapping. In 2011, this industry group in Florida had total output of $\$ 568$ million; exports or sales to Florida visitors of $\$ 226$ million; output impacts of $\$ 984$ million; direct employment of 7,762 jobs; employment impacts of 11,296 jobs; direct value added of $\$ 363$ million; value-added impacts of $\$ 626$ million; labor income impacts of $\$ 375$ million; other property-income impacts of $\$ 179$ million; and indirect business-tax impacts of $\$ 72$ million (Table 1, Figures 2 to 3). Among individual sectors, Golf courses had value-added impacts of \$554 million and employment impacts of 9,955 jobs, followed by Commercial hunting and trapping ( $\$ 68$ million; 1,274 jobs).

Food and Kindred Products Distribution includes activities for wholesale and retail trade in agricultural, food, and related products. This group of industry sectors is only indirectly related to agriculture and natural resources because it serves to deliver products to final consumers, but it is included here for a perspective on the scope of the complex market chain for food and kindred products. In 2011, this 
industry group in Florida had a total output of $\$ 67.15$ billion; exports of $\$ 12.99$ billion; output impacts of $\$ 90.37$ billion; direct employment of 989,278 jobs; employment impacts of 1,183,709 jobs; direct value added of $\$ 41.73$ billion; value-added impacts of $\$ 56.36$ billion; labor income impacts of $\$ 37.52$ billion; other property-income impacts of $\$ 10.87$ billion; and indirect business-tax impacts of $\$ 7.97$ billion (Table 1, Figures 2 to 3). Collectively, this group represented about 54 percent of total value-added impacts and 60 percent of employment impacts for all industries included in this report. Among individual sectors within this group, Food service establishments and drinking places (restaurants and bars) had the greatest value-added impacts (\$32.14 billion) and employment impacts $(814,808$ jobs), followed by Wholesale trade in food and kindred products ( $\$ 14.29$ billion; 135,219 jobs); Retail stores, food and beverage stores ( $\$ 9.47$ billion; 224,547 jobs); and Retail lawn and garden centers ( $\$ 461$ million; 9,135 jobs).

Excluding sectors for Food and Kindred Products Distribution, the total economic values for all other agriculture, natural resources, and related food industries were $\$ 63.22$ billion in direct output, including exports of $\$ 34.46$ billion; total output impacts of $\$ 108.53$ billion; direct employment of 418,642 jobs; employment impacts of 781,512 jobs; direct value added of $\$ 20.90$ billion; value-added impacts of $\$ 47.94$ billion; labor income impacts of $\$ 30.00$ billion; other property-income impacts of $\$ 14.09$ billion; and indirect business-tax impacts of $\$ 3.85$ billion (subtotaled in Table 1). 
Table 1. Summary of economic contributions of agriculture, natural resources, and related food industry groups and sectors in Florida in 2011

\begin{tabular}{|c|c|c|c|c|c|c|c|c|c|c|}
\hline \multirow{3}{*}{ Industry Group / Sector } & \multicolumn{2}{|c|}{ Employment } & \multicolumn{2}{|c|}{ Output (Revenue) } & \multirow{2}{*}{ Exports } & \multicolumn{2}{|c|}{ Value Added } & \multirow{2}{*}{$\begin{array}{l}\text { Labor } \\
\text { Income } \\
\text { Impacts }\end{array}$} & \multirow{2}{*}{$\begin{array}{l}\text { Other } \\
\text { Property } \\
\text { Income } \\
\text { Impacts }\end{array}$} & \multirow{2}{*}{$\begin{array}{c}\text { Indirect } \\
\text { Business } \\
\text { Tax } \\
\text { Impacts }\end{array}$} \\
\hline & Direct & $\begin{array}{l}\text { Total } \\
\text { Impacts }\end{array}$ & Direct & $\begin{array}{l}\text { Total } \\
\text { Impacts }\end{array}$ & & Direct & $\begin{array}{l}\text { Total } \\
\text { Impacts }\end{array}$ & & & \\
\hline & \multicolumn{2}{|c|}{$\begin{array}{l}\text { Full-time and Part-time } \\
\text { Jobs }\end{array}$} & & & & -1 & Dollars - & & & \\
\hline $\begin{array}{l}\text { Crop, Livestock, Forestry \& } \\
\text { Fisheries Production }\end{array}$ & 130,546 & 220,839 & 10,537 & 20,551 & 6,595 & 5,442 & 11,639 & 7,856 & 3,314 & 470 \\
\hline $\begin{array}{l}\text { Support activities for agriculture } \\
\text { and forestry }\end{array}$ & 50,138 & 63,360 & 1,249 & 2,869 & 925 & 906 & 1,905 & 1,748 & 47 & 110 \\
\hline $\begin{array}{l}\text { Greenhouse, nursery, and } \\
\text { floriculture production }\end{array}$ & 15,902 & 33,129 & 1,935 & 3,952 & 1,215 & 1,273 & 2,537 & 1,834 & 614 & 89 \\
\hline Fruit farming & 14,402 & 36,777 & 2,220 & 4,593 & 1,548 & 1,198 & 2,678 & 1,644 & 945 & 88 \\
\hline Sugarcane and sugar beet farming & 14,214 & 18,628 & 509 & 993 & 329 & 218 & 514 & 270 & 232 & 12 \\
\hline Vegetable and melon farming & 10,760 & 27,279 & 1,925 & 3,750 & 1,199 & 1,022 & 2,159 & 1,297 & 782 & 79 \\
\hline Commercial fishing & 6,510 & 7,981 & 184 & 361 & 163 & 69 & 178 & 102 & 65 & 11 \\
\hline Dairy cattle and milk production & 4,397 & 4,774 & 559 & 604 & 42 & 203 & 230 & 51 & 181 & -1 \\
\hline Cattle ranching and farming & 4,122 & 6,374 & 488 & 764 & 254 & 82 & 223 & 122 & 96 & 5 \\
\hline $\begin{array}{l}\text { Animal production, except cattle } \\
\text { and poultry and eggs }\end{array}$ & 2,867 & 2,911 & 102 & 107 & 4 & 51 & 54 & 22 & 34 & -1 \\
\hline Commercial logging & 2,770 & 3,357 & 187 & 253 & 53 & 75 & 115 & 117 & -9 & 7 \\
\hline $\begin{array}{l}\text { Forestry, forest products, and } \\
\text { timber tract production }\end{array}$ & 1,517 & 9,419 & 447 & 1,117 & 447 & 165 & 592 & 366 & 169 & 57 \\
\hline All other crop farming & 1,462 & 3,241 & 268 & 468 & 158 & 71 & 193 & 120 & 69 & 4 \\
\hline Poultry and egg production & 752 & 1,801 & 363 & 494 & 164 & 73 & 149 & 94 & 50 & 5 \\
\hline Cotton farming & 456 & 1,321 & 83 & 183 & 78 & 27 & 87 & 54 & 29 & 5 \\
\hline Tree nut farming & 148 & 284 & 12 & 26 & 9 & 7 & 16 & 10 & 5 & 1 \\
\hline Oilseed farming & 83 & 148 & 6 & 13 & 6 & 3 & 7 & 3 & 4 & 0 \\
\hline Grain farming & 48 & 56 & 2 & 3 & 1 & 1 & 1 & 1 & 1 & 0 \\
\hline Agricultural Inputs \& Services & 201,261 & 292,142 & 17,036 & 28,956 & 9,318 & 6,411 & 13,287 & 9,455 & 3,048 & 785 \\
\hline Landscape services & 139,957 & 178,799 & 7,352 & 11,977 & 3,148 & 3,847 & 6,727 & 4,981 & 1,389 & 357 \\
\hline Pest control services & 29,540 & 37,738 & 1,552 & 2,528 & 664 & 812 & 1,420 & 1,051 & 293 & 75 \\
\hline Veterinary services & 26,431 & 29,163 & 1,507 & 1,837 & 192 & 888 & 1,094 & 909 & 127 & 57 \\
\hline Fertilizer manufacturing & 4,916 & 44,777 & 6,312 & 12,126 & 5,170 & 771 & 3,855 & 2,409 & 1,160 & 286 \\
\hline $\begin{array}{l}\text { Farm machinery and equipment } \\
\text { manufacturing }\end{array}$ & 225 & 609 & 153 & 201 & 41 & 58 & 88 & 46 & 38 & 3 \\
\hline $\begin{array}{l}\text { Lawn and garden equipment } \\
\text { manufacturing }\end{array}$ & 110 & 112 & 47 & 47 & 0 & 13 & 13 & 7 & 5 & 0 \\
\hline $\begin{array}{l}\text { Pesticide and other agricultural } \\
\text { chemical manufacturing }\end{array}$ & 81 & 945 & 115 & 241 & 103 & 23 & 92 & 51 & 35 & 6 \\
\hline $\begin{array}{l}\text { Food \& Kindred Products } \\
\text { Manufacturing }\end{array}$ & 40,204 & 137,339 & 23,252 & 35,769 & 10,642 & 6,022 & 13,396 & 6,863 & 4,581 & 1,951 \\
\hline $\begin{array}{l}\text { Bread and bakery product } \\
\text { manufacturing }\end{array}$ & 7,295 & 7,705 & 1,173 & 1,223 & 35 & 332 & 362 & 283 & 67 & 12 \\
\hline Soft drink and ice manufacturing & 6,627 & 33,298 & 4,716 & 8,598 & 3,916 & 576 & 2,743 & 1,780 & 782 & 181 \\
\hline $\begin{array}{l}\text { Fruit and vegetable canning, } \\
\text { pickling, and drying }\end{array}$ & 3,393 & 18,394 & 1,783 & 3,758 & 1,602 & 415 & 1,576 & 963 & 523 & 91 \\
\hline Frozen food manufacturing & 3,009 & 11,964 & 1,012 & 2,154 & 919 & 239 & 932 & 615 & 259 & 59 \\
\hline All other food manufacturing & 2,651 & 4,107 & 827 & 1,010 & 134 & 173 & 283 & 183 & 90 & 10 \\
\hline $\begin{array}{l}\text { Fluid milk and butter } \\
\text { manufacturing }\end{array}$ & 1,745 & 1,885 & 1,782 & 1,801 & 13 & 217 & 227 & 101 & 119 & 6 \\
\hline Poultry processing & 1,740 & 2,024 & 636 & 675 & 34 & 87 & 109 & 69 & 38 & 3 \\
\hline
\end{tabular}




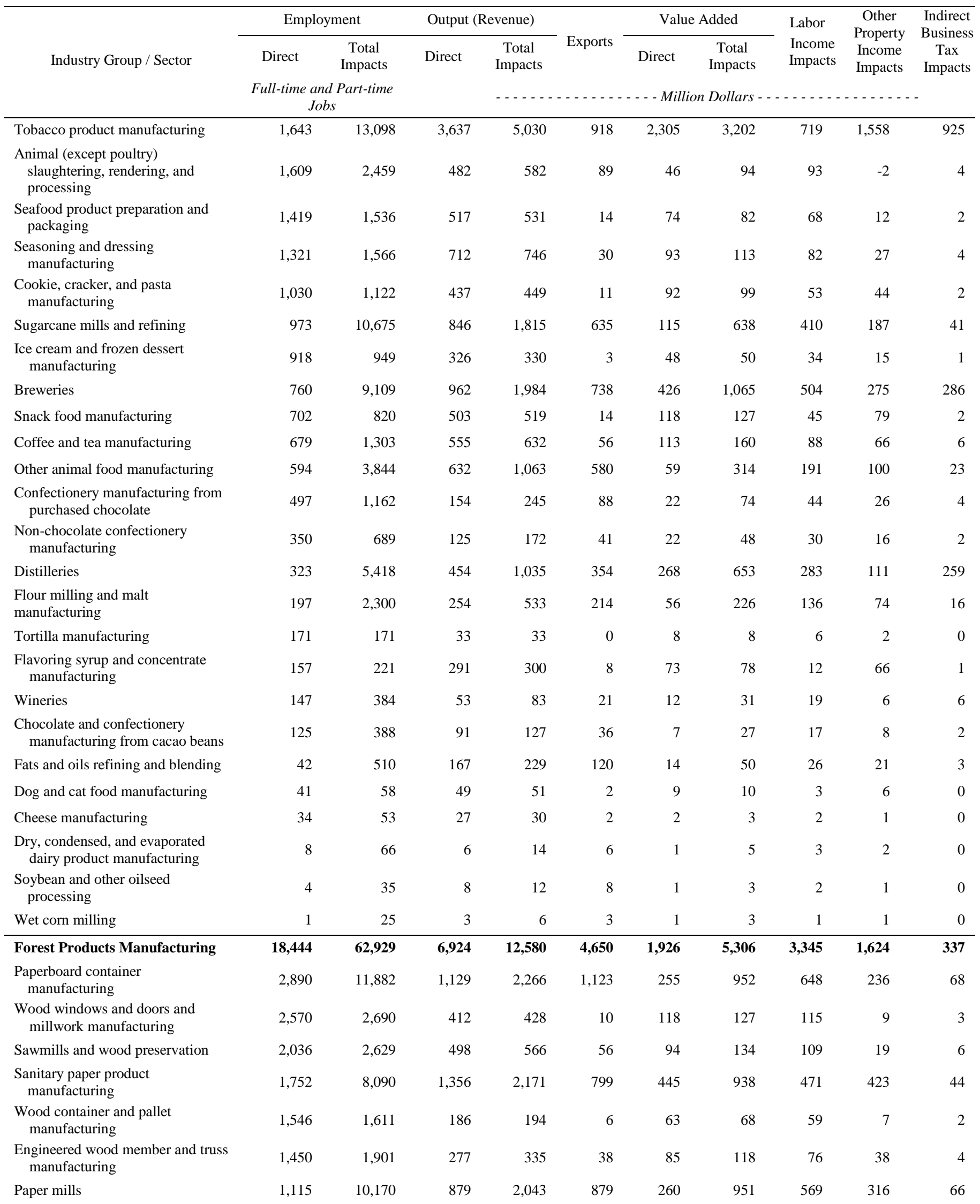




\begin{tabular}{|c|c|c|c|c|c|c|c|c|c|c|}
\hline \multirow{3}{*}{ Industry Group / Sector } & \multicolumn{2}{|c|}{ Employment } & \multicolumn{2}{|c|}{ Output (Revenue) } & \multirow{2}{*}{ Exports } & \multicolumn{2}{|c|}{ Value Added } & \multirow{2}{*}{$\begin{array}{l}\text { Labor } \\
\text { Income } \\
\text { Impacts }\end{array}$} & \multirow{2}{*}{$\begin{array}{c}\text { Other } \\
\text { Property } \\
\text { Income } \\
\text { Impacts }\end{array}$} & \multirow{2}{*}{$\begin{array}{c}\text { Indirect } \\
\text { Business } \\
\text { Tax } \\
\text { Impacts }\end{array}$} \\
\hline & Direct & $\begin{array}{c}\text { Total } \\
\text { Impacts }\end{array}$ & Direct & $\begin{array}{l}\text { Total } \\
\text { Impacts }\end{array}$ & & Direct & $\begin{array}{l}\text { Total } \\
\text { Impacts }\end{array}$ & & & \\
\hline & \multicolumn{2}{|c|}{$\begin{array}{l}\text { Full-time and Part-time } \\
\text { Jobs }\end{array}$} & & & & -1 & n Dollars - & & & \\
\hline $\begin{array}{l}\text { Veneer and plywood } \\
\text { manufacturing }\end{array}$ & 982 & 1,185 & 232 & 257 & 17 & 73 & 88 & 58 & 20 & 10 \\
\hline Stationery product manufacturing & 869 & 3,243 & 267 & 566 & 256 & 68 & 252 & 170 & 66 & 16 \\
\hline Pulp mills & 802 & 7,778 & 611 & 1,489 & 611 & 160 & 670 & 432 & 189 & 50 \\
\hline Paperboard Mills & 752 & 7,822 & 639 & 1,537 & 605 & 179 & 711 & 434 & 225 & 51 \\
\hline $\begin{array}{l}\text { All other miscellaneous wood } \\
\text { product manufacturing }\end{array}$ & 608 & 765 & 99 & 119 & 12 & 31 & 42 & 31 & 11 & 1 \\
\hline $\begin{array}{l}\text { Coated and laminated paper, } \\
\text { packaging paper and plastics } \\
\text { film manufacturing }\end{array}$ & 401 & 1,651 & 155 & 318 & 151 & 46 & 143 & 94 & 41 & 8 \\
\hline $\begin{array}{l}\text { All other paper bag and coated and } \\
\text { treated paper manufacturing }\end{array}$ & 249 & 335 & 77 & 88 & 11 & 19 & 26 & 21 & 4 & 1 \\
\hline $\begin{array}{l}\text { All other converted paper product } \\
\text { manufacturing }\end{array}$ & 239 & 945 & 72 & 161 & 72 & 18 & 73 & 48 & 20 & 5 \\
\hline $\begin{array}{l}\text { Reconstituted wood product } \\
\text { manufacturing }\end{array}$ & 184 & 233 & 36 & 42 & 5 & 11 & 15 & 13 & 2 & 1 \\
\hline Mining & 20,425 & 56,966 & 4,908 & 9,692 & 3,027 & 740 & 3,686 & 2,105 & 1,342 & 239 \\
\hline Extraction of oil and natural gas & 15,220 & 39,094 & 3,565 & 6,766 & 1,954 & 98 & 2,076 & 1,203 & 731 & 142 \\
\hline $\begin{array}{l}\text { Mining and quarrying other } \\
\text { nonmetallic minerals }\end{array}$ & 1,897 & 5,981 & 542 & 1,051 & 340 & 285 & 598 & 323 & 239 & 36 \\
\hline $\begin{array}{l}\text { Mining and quarrying sand, gravel, } \\
\text { clay, and ceramic and refractory } \\
\text { minerals }\end{array}$ & 1,124 & 3,328 & 184 & 459 & 184 & 95 & 264 & 167 & 81 & 16 \\
\hline Mining and quarrying stone & 1,067 & 4,204 & 248 & 633 & 248 & 149 & 386 & 201 & 163 & 22 \\
\hline $\begin{array}{l}\text { Support activities for oil and gas } \\
\text { operations }\end{array}$ & 463 & 1,367 & 76 & 188 & 70 & 25 & 93 & 64 & 23 & 6 \\
\hline Drilling oil and gas wells & 351 & 2,064 & 180 & 406 & 176 & 36 & 170 & 98 & 60 & 11 \\
\hline $\begin{array}{l}\text { Mining gold, silver, and other } \\
\text { metal ore }\end{array}$ & 139 & 234 & 62 & 74 & 8 & 42 & 49 & 14 & 32 & 3 \\
\hline Support activities for other mining & 139 & 633 & 43 & 103 & 43 & 8 & 45 & 30 & 12 & 3 \\
\hline Mining coal & 24 & 62 & 7 & 12 & 3 & 3 & 6 & 3 & 2 & 1 \\
\hline Nature-based Recreation & 7,762 & 11,296 & 568 & 984 & 226 & 363 & 626 & 375 & 179 & 72 \\
\hline Golf courses & 6,507 & 9,955 & 417 & 823 & 219 & 298 & 554 & 364 & 132 & 59 \\
\hline Commercial hunting and trapping & 1,211 & 1,274 & 148 & 155 & 5 & 64 & 68 & 9 & 47 & 13 \\
\hline $\begin{array}{l}\text { Recreational fishing \& hunting } \\
\text { guides }\end{array}$ & 44 & 67 & 3 & 6 & 1 & 2 & 4 & 2 & 1 & 0 \\
\hline $\begin{array}{l}\text { Subtotal excluding distribution } \\
\text { sectors }\end{array}$ & 418,642 & 781,512 & 63,225 & 108,531 & 34,458 & 20,904 & 47,941 & 29,999 & 14,089 & 3,853 \\
\hline $\begin{array}{l}\text { Food \& Kindred Products } \\
\text { Distribution }\end{array}$ & 989,278 & $1,183,709$ & 67,147 & 90,367 & 12,989 & 41,728 & 56,358 & 37,518 & 10,870 & 7,970 \\
\hline Food services and drinking places & 700,531 & 814,808 & 41,385 & 55,213 & 8,063 & 23,494 & 32,141 & 21,835 & 6,688 & 3,618 \\
\hline Retail Stores, food and beverage & 199,728 & 224,547 & 11,069 & 13,986 & 1,496 & 7,607 & 9,466 & 6,896 & 789 & 1,780 \\
\hline $\begin{array}{l}\text { Wholesale trade, food \& kindred } \\
\text { products }\end{array}$ & 80,208 & 135,219 & 14,044 & 20,481 & 3,411 & 10,190 & 14,290 & 8,459 & 3,358 & 2,474 \\
\hline Retail lawn and garden centers & 8,811 & 9,135 & 649 & 687 & 20 & 436 & 461 & 328 & 35 & 98 \\
\hline Grand Total & $1,407,920$ & $1,965,221$ & 130,372 & 198,898 & 47,447 & 62,632 & 104,299 & 67,516 & 24,959 & 11,823 \\
\hline
\end{tabular}

Source: IMPLAN data for Florida (MIG, Inc.). Total impact estimates include regional multiplier effects. 


\section{Economic Contributions by Agriculture and Natural Resource Commodity Groups}

In addition to the industry groups noted above, information on economic contributions was reorganized to evaluate groups of food and fiber commodities having identifiable market-chain linkages between producers, manufacturers, and service sectors. In this section, some sectors are regrouped to reflect these linkages, with results summarized in Figures 4 to 5. Environmental Horticulture, which includes the sectors Nursery and greenhouse production, Landscape services, and Retail lawn and garden centers, had combined value-added impacts of \$9.72 billion and employment impacts of 221,063 jobs. Agricultural Inputs and Services, including Fertilizer manufacturing, Farm machinery and equipment manufacturing, Lawn and garden equipment, and Pesticide and other agricultural chemical manufacturing, had combined value-added impacts of \$7.04 billion and employment impacts of 138,965 jobs. Fruit and Vegetable Farming and Processing, including sectors for Fruit farming, Vegetable and melon farming, Frozen food manufacturing, and Fruit and vegetable canning, pickling and drying had combined value-added impacts of $\$ 7.36$ billion and employment impacts of 94,698 jobs. Forestry and Forest Products, including the sectors Forestry and timber tracts, and Logging as well as 16 forest product manufacturing sectors, had combined value-added impacts of \$6.01 billion and employment impacts of 75,704 jobs. Sugarcane Farming and Refined Sugar and Confections Manufacturing had combined value-added impacts of \$1.15 billion and employment impacts of 29,303 jobs. Livestock and Dairy Farming, and Animal Products Manufacturing, including the production sectors Beef cattle ranching and farming, Dairy cattle and milk production, Poultry and egg production, Animal production except cattle and poultry, Animal slaughtering, Poultry processing, Cheese manufacturing, and Ice cream manufacturing, had combined value-added impacts of $\$ 1.14$ billion and employment impacts of 23,296 jobs. Fishing and Seafood Products combined had value-added impacts of \$260 million and employment impacts of 9,518 jobs. The group Grain and Oilseed Farming and Processing had combined value-added and employment impacts of \$291 million and 3,073 jobs. 
Figure 4. Output and value-added contributions of food and fiber commodity groups in Florida in 2011

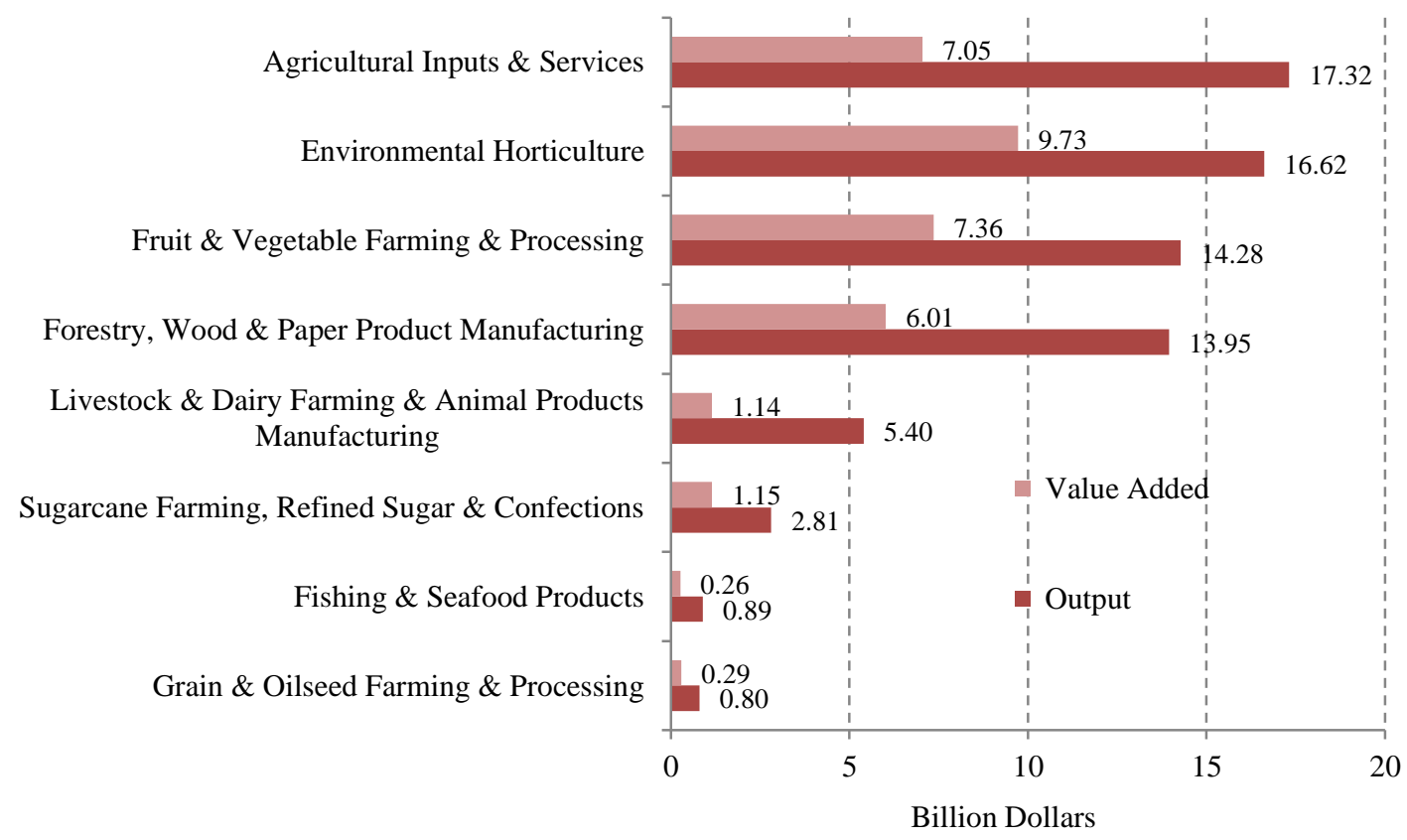

Source: IMPLAN data for Florida (MIG, Inc.). Estimates include regional multiplier effects.

Figure 5. Employment contributions of food and fiber commodity groups in Florida in 2011

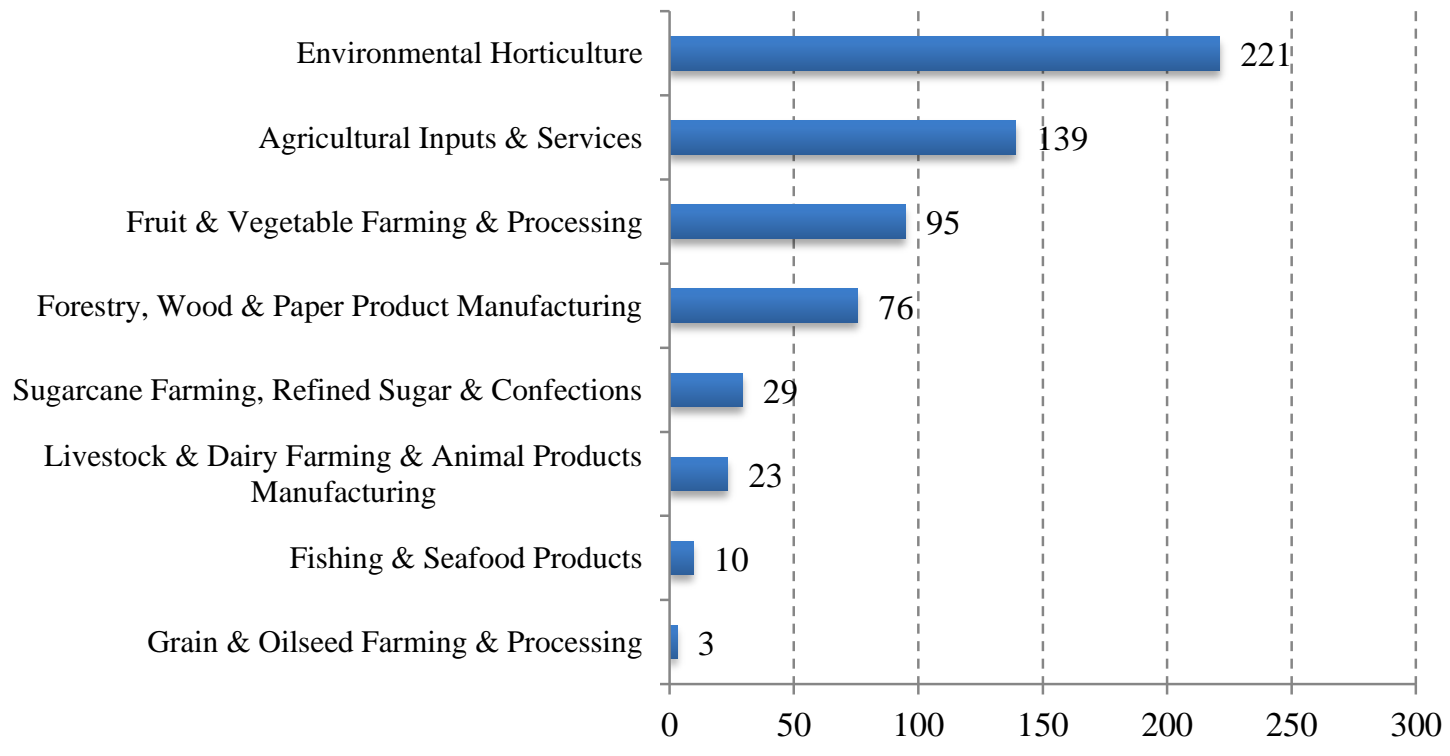

Full-time and Part-time Jobs (thousands)

Source: IMPLAN data for Florida (MIG, Inc.). Estimates include regional multiplier effects. 


\section{Economic Contributions in Florida Regions and Counties}

Regional impacts of agriculture, natural resources, and related food industries in 2011 were evaluated for all 67 Florida counties and 9 multi-county economic regions as shown in Figure 6, with results summarized in Tables 2 to 3, and Figures 7 to 9. Value-added and employment impacts were highest in the Miami-Ft. Lauderdale region ( $\$ 34.82$ billion; 641,007 jobs), followed by Orlando ( $\$ 25.05$ billion; 489,440 jobs); Tampa-St. Petersburg ( $\$ 15.04$ billion; 273,410 jobs); Jacksonville ( $\$ 10.76$ billion; 161,615 jobs); Sarasota-Bradenton ( $\$ 9.63$ billion; 199,048 jobs); Pensacola ( $\$ 2.82$ billion; 64,959 jobs); Tallahassee ( $\$ 2.39$ billion; 48,526 jobs); Gainesville ( $\$ 2.22$ billion; 53,112 jobs); and Panama City ( $\$ 1.56$ billion; 34,103 jobs).

Among individual Florida counties, the eight largest counties in terms of value-added impacts and employment impacts in 2009 were Miami-Dade ( $\$ 13.20$ billion; 222,402 jobs), followed by Hillsborough ( $\$ 9.27$ billion; 148,158 jobs); Orange ( $\$ 8.31$ billion; 155,653 jobs); Broward ( $\$ 8.03$ billion; 159,638 jobs); Palm Beach ( $\$ 8.20$ billion; 148,994 jobs); Duval ( $\$ 7.91$ billion; 110,550 jobs); Polk ( $\$ 6.10$ billion; 93,237 jobs); and Pinellas ( $\$ 4.32$ billion; 87,981 jobs). Fifteen other counties with value-added impacts exceeding $\$ 1$ billion were Lee ( $\$ 2.51$ billion); Manatee ( $\$ 2.36$ billion); Collier ( $\$ 2.17$ billion); Seminole ( $\$ 2.00$ billion); Volusia ( $\$ 1.65$ billion); Sarasota (\$1.63 billion); Brevard (\$1.40 billion); Lake (\$1.38 billion); Escambia (\$1.23 billion); Marion (\$1.17 billion); Bay ( $\$ 1.15$ billion); St. Lucie ( $\$ 1.13$ billion); Pasco (\$1.06 billion); Indian River ( $\$ 1.06$ billion); and Alachua (\$1.04 billion). Thematic maps of the total employment and value-added impacts for Florida counties are shown in Figures 8 and 9, respectively.

Additional detailed information on economic contributions in individual Florida counties is available at http://www.fred.ifas.ufl.edu/economic-impact-analysis/Florida-county-profiles-2011.pdf. 
Figure 6. Functional economic regions of Florida

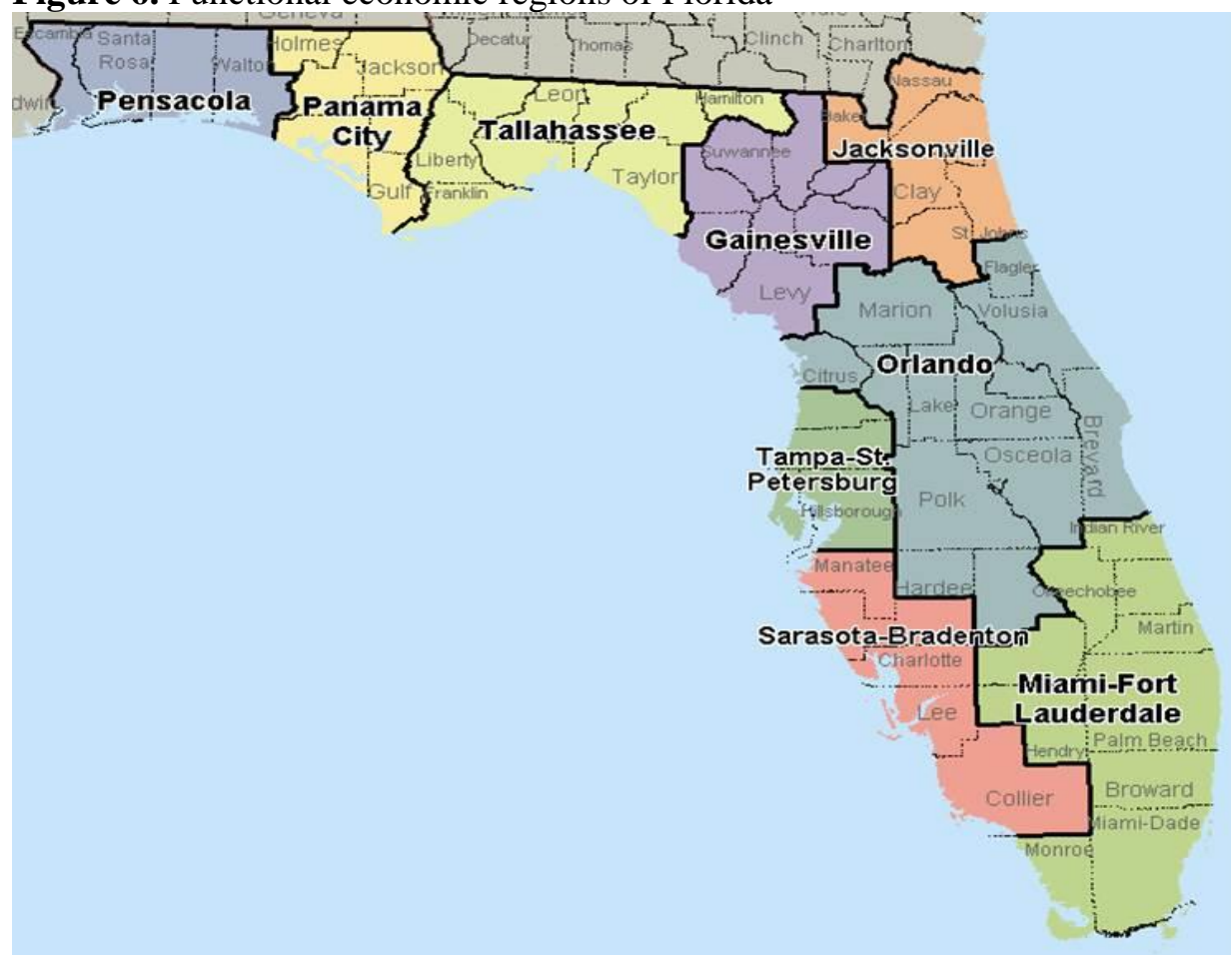

Adapted from U.S. Commerce Department, Bureau of Economic Analysis (Johnson and Kort 2004).

Figure 7. Employment contributions of agriculture, natural resources, and related food industries in Florida regions in 2011

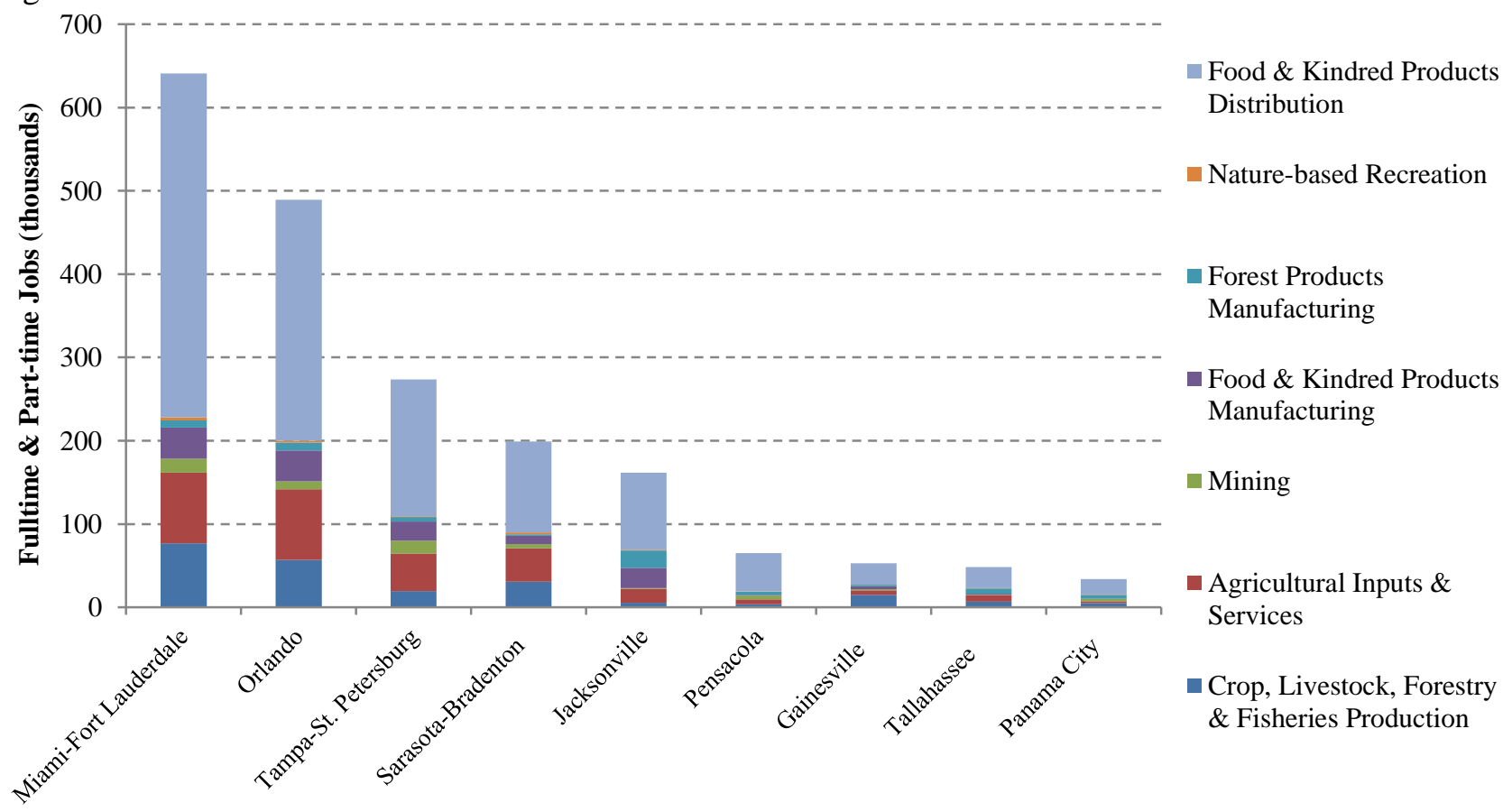

Source: IMPLAN data for Florida (MIG, Inc.). Estimates include regional multiplier effects. 
Figure 8. Map of total value-added contributions by agriculture, natural resources, and related food industries in Florida counties in 2011

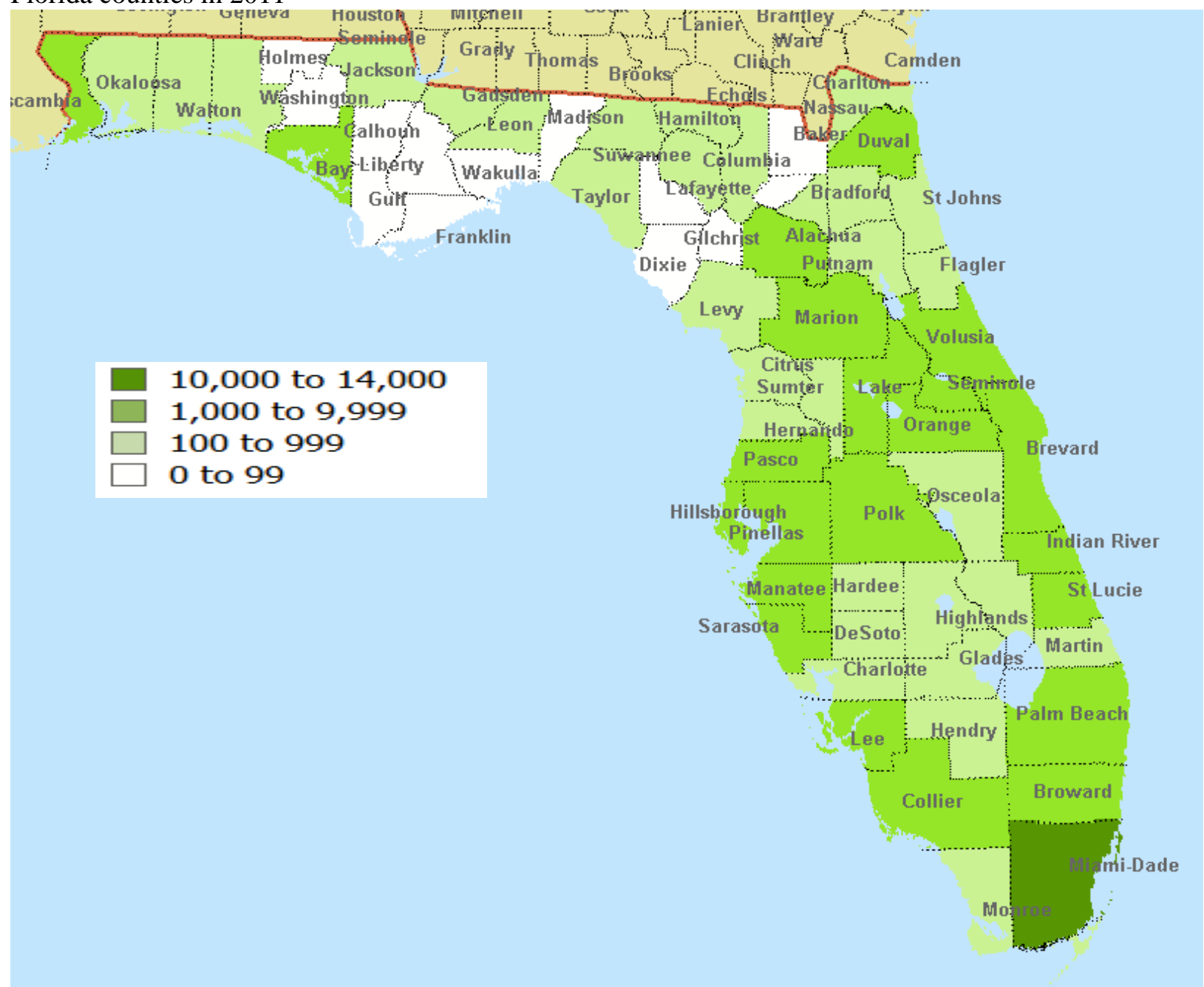

Values given in million dollars. Estimates include regional multiplier effects.

Source: IMPLAN data for Florida (MIG, Inc.). 
Figure 9. Map of total employment contributions by agriculture, natural resources, and related food industries in Florida counties in 2011

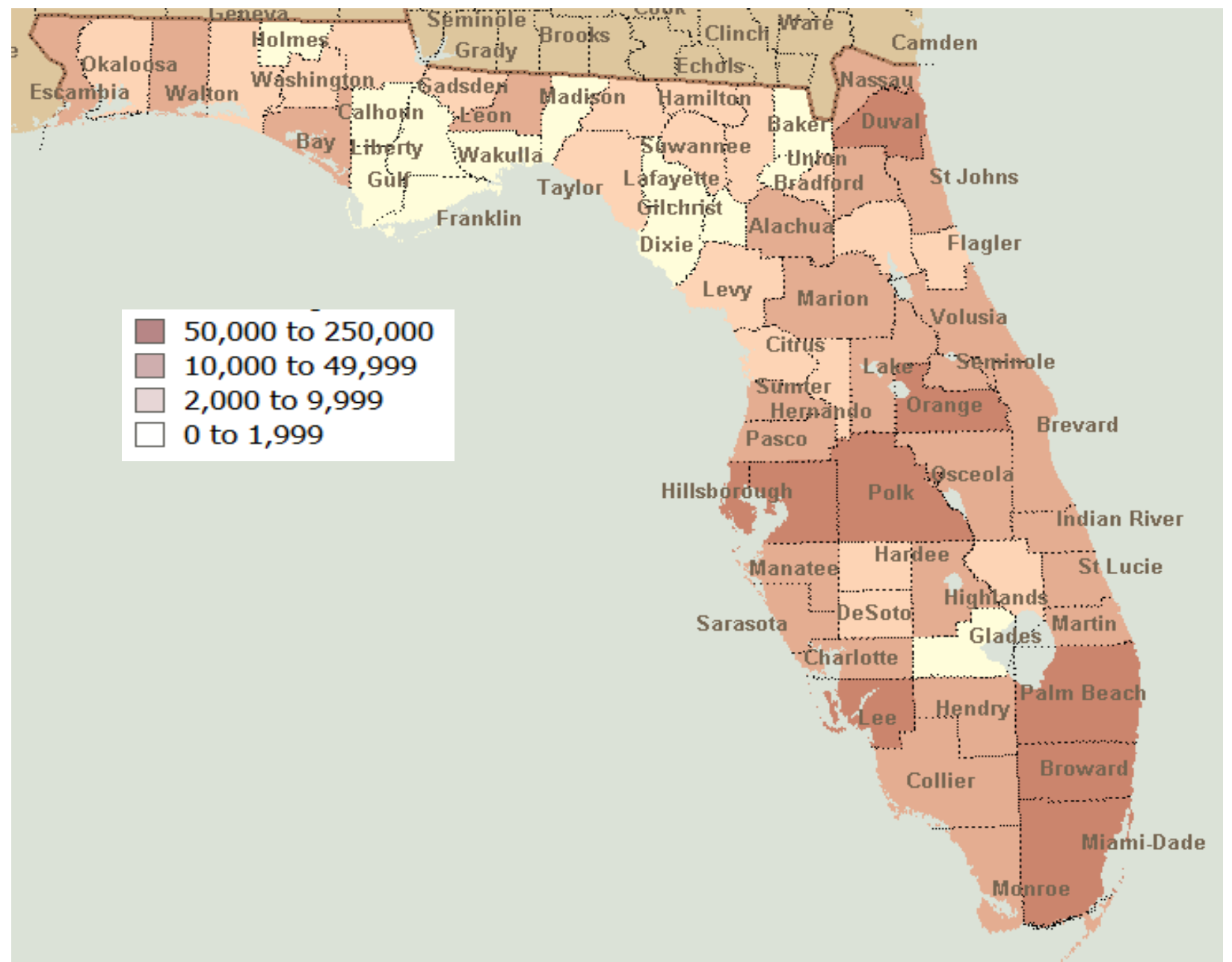

Estimates represent full-time and part-time jobs, and include regional multiplier effects.

Source: IMPLAN data for Florida (MIG, Inc.). 
Table 2. Summary of economic contributions of agriculture, natural resources, and related food industries in Florida regions and counties in 2011

\begin{tabular}{|c|c|c|c|c|c|c|c|c|c|c|}
\hline Region / County & $\begin{array}{c}\text { Direct } \\
\text { Employ- } \\
\text { ment } \\
\text { (Jobs) }\end{array}$ & $\begin{array}{l}\text { Direct } \\
\text { Output } \\
(\$ M)\end{array}$ & $\begin{array}{c}\text { Direct } \\
\text { Value } \\
\text { Added } \\
(\$ M)\end{array}$ & $\begin{array}{c}\text { Exports } \\
(\$ M)\end{array}$ & $\begin{array}{l}\text { Output } \\
\text { Impacts } \\
(\$ M)\end{array}$ & $\begin{array}{c}\text { Employ- } \\
\text { ment } \\
\text { Impacts } \\
\text { (Jobs) }\end{array}$ & $\begin{array}{l}\text { Value- } \\
\text { Added } \\
\text { Impacts } \\
(\$ \mathrm{M})\end{array}$ & $\begin{array}{l}\text { Labor } \\
\text { Income } \\
\text { Impacts } \\
(\$ M)\end{array}$ & $\begin{array}{c}\text { Other } \\
\text { Property } \\
\text { Income } \\
\text { Impacts } \\
(\$ M)\end{array}$ & $\begin{array}{c}\text { Indirect } \\
\text { Business } \\
\text { Tax } \\
\text { Impacts } \\
(\$ M)\end{array}$ \\
\hline Gainesville & 40,312 & $3,784.6$ & $1,417.4$ & $2,015.6$ & $5,229.6$ & 53,112 & $2,221.4$ & $1,310.8$ & 675.5 & 218.4 \\
\hline Alachua & 21,538 & $1,441.0$ & 682.3 & 508.1 & $2,074.5$ & 27,223 & $1,041.0$ & 661.6 & 248.0 & 127.6 \\
\hline Bradford & 1,772 & 203.1 & 95.5 & 112.9 & 270.4 & 2,353 & 133.0 & 64.1 & 57.1 & 9.7 \\
\hline Columbia & 4,501 & 365.4 & 151.6 & 150.3 & 522.1 & 6,093 & 240.2 & 140.8 & 72.3 & 24.9 \\
\hline Dixie & 1,217 & 133.6 & 41.3 & 11.2 & 148.8 & 1,356 & 51.1 & 34.6 & 13.1 & 2.9 \\
\hline Gilchrist & 1,196 & 192.9 & 57.0 & 148.3 & 274.5 & 1,706 & 97.6 & 50.7 & 41.6 & 5.4 \\
\hline Lafayette & 614 & 115.1 & 40.5 & 93.6 & 139.8 & 771 & 54.1 & 20.1 & 32.6 & 2.3 \\
\hline Levy & 2,870 & 189.8 & 90.1 & 95.5 & 304.4 & 3,961 & 161.4 & 112.5 & 34.2 & 12.1 \\
\hline Suwannee & 5,895 & $1,055.7$ & 237.9 & 833.1 & $1,371.2$ & 8,556 & 405.8 & 204.6 & 163.7 & 30.9 \\
\hline Union & 709 & 88.0 & 21.2 & 62.7 & 123.9 & 1,093 & 37.1 & 21.7 & 12.8 & 2.5 \\
\hline Jacksonville & 104,450 & $13,291.1$ & $6,452.1$ & 7,478.0 & $20,305.8$ & 161,615 & $10,755.7$ & $6,029.4$ & $3,091.2$ & $1,630.7$ \\
\hline Baker & 1,039 & 64.5 & 30.0 & 17.1 & 83.1 & 1,241 & 40.3 & 21.7 & 13.6 & 4.6 \\
\hline Clay & 9,676 & 670.0 & 311.9 & 145.0 & 817.8 & 11,072 & 395.8 & 252.0 & 89.6 & 52.4 \\
\hline Duval & 69,320 & $9,472.7$ & $4,794.6$ & $5,646.9$ & $14,493.2$ & 110,550 & $7,908.2$ & $4,266.8$ & $2,284.0$ & $1,381.2$ \\
\hline Nassau & 5,272 & 865.9 & 334.7 & 599.1 & $1,653.4$ & 11,269 & 815.0 & 522.1 & 224.3 & 65.2 \\
\hline Putnam & 4,823 & $1,179.1$ & 410.3 & 657.7 & $1,781.2$ & 9,364 & 754.3 & 396.2 & 303.2 & 32.2 \\
\hline St. Johns & 14,320 & $1,038.9$ & 570.6 & 412.2 & $1,477.0$ & 18,119 & 842.0 & 570.6 & 176.6 & 95.0 \\
\hline Miami-Fort Lauderdale & 467,894 & $41,374.5$ & $21,653.1$ & $17,259.3$ & $62,543.4$ & 641,007 & $34,824.8$ & $23,117.4$ & $7,926.7$ & $3,685.9$ \\
\hline Broward & 123,490 & $9,882.8$ & $5,329.3$ & $3,268.4$ & $14,249.6$ & 159,638 & $8,030.2$ & $5,381.5$ & $1,684.3$ & 971.4 \\
\hline Glades & 1,104 & 174.5 & 64.5 & 135.7 & 300.6 & 1,814 & 132.2 & 66.5 & 56.9 & 3.4 \\
\hline Hendry & 8,190 & 803.3 & 397.2 & 634.1 & $1,556.4$ & 15,280 & 846.8 & 612.9 & 206.2 & 18.5 \\
\hline Indian River & 14,607 & $1,088.9$ & 582.1 & 575.5 & $1,841.7$ & 21,209 & $1,059.8$ & 700.5 & 273.4 & 66.8 \\
\hline Martin & 14,146 & $1,187.3$ & 579.2 & 540.1 & $1,877.3$ & 19,816 & 996.4 & 624.7 & 277.6 & 86.4 \\
\hline Miami-Dade & 164,143 & $15,754.5$ & $8,585.3$ & $5,981.0$ & $23,039.1$ & 222,402 & $13,197.4$ & $8,632.6$ & $2,963.6$ & $1,576.4$ \\
\hline Monroe & 15,773 & $1,279.2$ & 491.2 & 923.9 & $2,048.9$ & 23,609 & 905.5 & 634.7 & 190.9 & 90.7 \\
\hline Okeechobee & 3,890 & 598.7 & 170.0 & 418.3 & 893.9 & 6,226 & 326.1 & 213.4 & 92.3 & 18.6 \\
\hline Palm Beach & 106,880 & $9,312.4$ & $4,787.4$ & $4,245.5$ & $14,686.3$ & 148,994 & $8,200.4$ & $5,544.1$ & $1,887.4$ & 753.7 \\
\hline St. Lucie & 15,671 & $1,293.0$ & 666.9 & 536.8 & $2,049.7$ & 22,018 & $1,130.0$ & 706.6 & 294.1 & 100.0 \\
\hline Orlando & 347,135 & $31,910.0$ & $14,622.5$ & $15,063.5$ & $49,512.4$ & 489,440 & $25,047.3$ & $16,254.3$ & $6,054.4$ & $3,092.9$ \\
\hline Brevard & 30,486 & $2,011.2$ & $1,102.2$ & 179.7 & $2,505.8$ & 34,941 & $1,398.4$ & 896.1 & 291.7 & 201.7 \\
\hline Citrus & 6,387 & 389.2 & 205.1 & 77.3 & 503.4 & 7,555 & 271.4 & 175.1 & 58.7 & 37.3 \\
\hline Flagler & 4,534 & 303.3 & 169.1 & 83.8 & 412.5 & 5,452 & 236.4 & 153.1 & 55.6 & 25.8 \\
\hline Hardee & 4,770 & 500.4 & 238.9 & 379.5 & 900.9 & 8,391 & 479.8 & 278.4 & 179.8 & 13.3 \\
\hline Highlands & 9,560 & 797.7 & 372.4 & 479.3 & $1,462.5$ & 15,965 & 748.9 & 484.8 & 209.3 & 40.0 \\
\hline Lake & 19,059 & $1,906.4$ & 744.1 & 940.9 & $3,060.3$ & 28,809 & $1,380.7$ & 834.0 & 409.9 & 110.3 \\
\hline Marion & 21,684 & $1,640.6$ & 754.6 & 623.5 & $2,347.9$ & 28,339 & $1,168.9$ & 768.4 & 268.1 & 119.5 \\
\hline Orange & 116,492 & $9,720.2$ & $5,081.8$ & $5,057.7$ & $14,855.3$ & 155,653 & $8,305.9$ & $5,669.6$ & $1,786.9$ & 821.6 \\
\hline Osceola & 17,714 & $1,241.4$ & 656.4 & 506.3 & $1,779.3$ & 22,235 & 984.8 & 639.4 & 230.9 & 107.0 \\
\hline Polk & 46,444 & $8,320.0$ & $2,640.1$ & $5,137.1$ & $14,398.4$ & 93,237 & $6,096.0$ & $3,767.9$ & $1,654.1$ & $1,155.4$ \\
\hline
\end{tabular}




\begin{tabular}{|c|c|c|c|c|c|c|c|c|c|c|}
\hline Region / County & $\begin{array}{c}\text { Direct } \\
\text { Employ- } \\
\text { ment } \\
\text { (Jobs) }\end{array}$ & $\begin{array}{c}\text { Direct } \\
\text { Output } \\
(\$ M)\end{array}$ & $\begin{array}{c}\text { Direct } \\
\text { Value } \\
\text { Added } \\
(\$ M)\end{array}$ & $\begin{array}{l}\text { Exports } \\
(\$ \mathrm{M})\end{array}$ & $\begin{array}{c}\text { Output } \\
\text { Impacts } \\
(\$ M)\end{array}$ & $\begin{array}{l}\text { Employ- } \\
\text { ment } \\
\text { Impacts } \\
\text { (Jobs) }\end{array}$ & $\begin{array}{l}\text { Value- } \\
\text { Added } \\
\text { Impacts } \\
(\$ \mathrm{M})\end{array}$ & $\begin{array}{l}\text { Labor } \\
\text { Income } \\
\text { Impacts } \\
(\$ M)\end{array}$ & $\begin{array}{c}\text { Other } \\
\text { Property } \\
\text { Income } \\
\text { Impacts } \\
(\$ M)\end{array}$ & $\begin{array}{c}\text { Indirect } \\
\text { Business } \\
\text { Tax } \\
\text { Impacts } \\
(\$ M)\end{array}$ \\
\hline Seminole & 31,142 & $2,371.4$ & $1,294.0$ & 881.3 & $3,530.2$ & 40,619 & $2,005.4$ & $1,316.0$ & 453.3 & 231.0 \\
\hline Sumter & 6,355 & 544.0 & 210.8 & 185.3 & 743.3 & 8,050 & 316.0 & 219.5 & 62.5 & 32.5 \\
\hline Volusia & 32,507 & $2,164.2$ & $1,152.9$ & 531.9 & $3,012.4$ & 40,194 & $1,654.8$ & $1,051.9$ & 393.6 & 197.5 \\
\hline Panama City & 23,364 & $2,103.2$ & 849.1 & $1,105.7$ & $3,354.0$ & 34,103 & $1,556.8$ & 952.2 & 432.5 & 164.9 \\
\hline Bay & 16,036 & $1,461.9$ & 608.2 & 762.1 & $2,410.7$ & 23,840 & $1,152.1$ & 704.4 & 314.3 & 128.2 \\
\hline Calhoun & 879 & 79.1 & 32.5 & 48.0 & 121.7 & 1,291 & 59.0 & 45.2 & 10.4 & 5.4 \\
\hline Gulf & 741 & 41.7 & 22.8 & 9.3 & 53.7 & 859 & 30.0 & 20.9 & 5.2 & 3.9 \\
\hline Holmes & 1,291 & 78.3 & 25.5 & 39.0 & 109.9 & 1,781 & 40.9 & 17.4 & 18.5 & 3.9 \\
\hline Jackson & 2,974 & 348.2 & 127.5 & 202.7 & 520.7 & 4,283 & 221.9 & 123.9 & 76.4 & 16.5 \\
\hline Washington & 1,443 & 94.1 & 32.6 & 44.7 & 137.4 & 2,049 & 53.1 & 40.4 & 7.8 & 7.1 \\
\hline Pensacola & 49,256 & $3,769.0$ & $1,731.3$ & $1,509.9$ & $5,664.3$ & 64,959 & $2,822.2$ & $1,757.3$ & 720.5 & 313.0 \\
\hline Escambia & 18,743 & $1,562.5$ & 705.8 & 627.1 & $2,450.8$ & 26,031 & $1,235.3$ & 779.8 & 316.4 & 135.7 \\
\hline Okaloosa & 16,989 & $1,223.7$ & 562.2 & 464.9 & $1,811.6$ & 21,798 & 873.9 & 528.5 & 220.5 & 101.1 \\
\hline Santa Rosa & 7,363 & 492.2 & 222.6 & 115.0 & 675.2 & 9,022 & 329.7 & 213.4 & 75.8 & 40.4 \\
\hline Walton & 6,160 & 490.5 & 240.7 & 302.8 & 726.8 & 8,108 & 383.4 & 235.6 & 107.7 & 35.7 \\
\hline Sarasota-Bradenton & 147,569 & $11,304.3$ & $5,867.1$ & $4,613.2$ & $17,319.3$ & 199,048 & $9,633.8$ & $6,614.4$ & $2,074.4$ & 886.4 \\
\hline Charlotte & 10,518 & 666.4 & 332.7 & 173.9 & 968.3 & 13,286 & 505.1 & 330.5 & 108.7 & 57.6 \\
\hline Collier & 30,577 & $2,257.3$ & $1,291.7$ & $1,105.6$ & $3,561.2$ & 41,534 & $2,168.0$ & $1,592.5$ & 398.2 & 182.0 \\
\hline De Soto & 4,999 & 459.5 & 228.6 & 350.9 & 840.8 & 8,259 & 462.6 & 298.7 & 140.4 & 10.2 \\
\hline Lee & 44,843 & $3,195.2$ & $1,705.8$ & 981.7 & $4,503.3$ & 56,049 & $2,515.3$ & $1,689.5$ & 546.2 & 275.8 \\
\hline Manatee & 26,617 & $2,732.3$ & $1,226.7$ & $1,369.1$ & $4,568.8$ & 42,438 & $2,355.8$ & $1,608.8$ & 536.3 & 177.0 \\
\hline Sarasota & 30,014 & $1,993.7$ & $1,081.6$ & 631.9 & $2,876.9$ & 37,482 & $1,627.1$ & $1,094.4$ & 344.6 & 183.8 \\
\hline Tallahassee & 33,522 & $3,603.2$ & $1,325.7$ & $2,068.7$ & $5,677.0$ & 48,526 & $2,395.0$ & $1,525.7$ & 628.1 & 225.5 \\
\hline Franklin & 1,245 & 110.6 & 40.3 & 69.4 & 136.0 & 1,486 & 55.2 & 35.1 & 13.1 & 6.5 \\
\hline Gadsden & 2,629 & 341.9 & 175.5 & 214.6 & 546.1 & 4,182 & 308.8 & 210.2 & 76.8 & 21.4 \\
\hline Hamilton & 1,213 & 812.7 & 116.1 & 607.3 & $1,365.4$ & 3,400 & 323.2 & 193.5 & 106.9 & 7.0 \\
\hline Jefferson & 994 & 85.3 & 40.7 & 53.6 & 137.4 & 1,489 & 71.9 & 36.7 & 29.9 & 4.3 \\
\hline Leon & 21,593 & $1,260.2$ & 668.9 & 356.1 & $1,702.6$ & 25,457 & 931.6 & 593.5 & 207.7 & 129.4 \\
\hline Liberty & 454 & 77.1 & 24.9 & 49.6 & 107.9 & 690 & 42.1 & 27.4 & 11.3 & 2.4 \\
\hline Madison & 1,696 & 219.4 & 54.3 & 174.1 & 330.6 & 2,774 & 107.0 & 80.4 & 19.4 & 9.1 \\
\hline Taylor & 2,332 & 622.1 & 173.3 & 522.4 & $1,254.8$ & 7,430 & 512.3 & 322.8 & 151.4 & 39.8 \\
\hline Wakulla & 1,367 & 74.1 & 31.6 & 21.7 & 96.3 & 1,618 & 43.0 & 26.1 & 11.5 & 5.6 \\
\hline Tampa-St. Petersburg & 192,799 & $19,062.9$ & $8,605.0$ & $8,428.6$ & $29,292.3$ & 273,410 & $15,041.4$ & $9,954.6$ & $3,355.5$ & $1,605.8$ \\
\hline Hernando & 9,056 & 571.7 & 294.3 & 107.4 & 753.3 & 10,804 & 400.0 & 238.5 & 99.4 & 55.9 \\
\hline Hillsborough & 95,440 & $11,450.5$ & $5,054.8$ & $6,010.2$ & $18,240.8$ & 148,158 & $9,268.2$ & $6,203.4$ & $2,029.3$ & 941.0 \\
\hline Pasco & 21,648 & $1,491.3$ & 737.3 & 407.4 & $2,040.6$ & 26,468 & $1,055.8$ & 696.8 & 224.7 & 126.7 \\
\hline Pinellas & 66,655 & $5,549.4$ & $2,518.6$ & $1,903.7$ & $8,257.7$ & 87,981 & $4,317.5$ & $2,815.9$ & $1,002.1$ & 482.2 \\
\hline Total All Regions & $1,406,301$ & 130,203 & 62,523 & 59,543 & 198,898 & $1,965,221$ & 104,299 & 67,516 & 24,959 & 11,823 \\
\hline
\end{tabular}

Source: IMPLAN data for Florida (MIG, Inc.). Impact estimates include regional multiplier effects. 
Table 3. Employment contributions of agriculture, natural resources, and related food industry groups in Florida regions and counties in 2011

\begin{tabular}{|c|c|c|c|c|c|c|c|c|}
\hline Region / County & $\begin{array}{c}\text { Crop, } \\
\text { Livestock, } \\
\text { Forestry \& } \\
\text { Fisheries } \\
\text { Production }\end{array}$ & $\begin{array}{l}\text { Agricultural } \\
\text { Inputs \& } \\
\text { Services }\end{array}$ & Mining & $\begin{array}{c}\text { Food \& } \\
\text { Kindred } \\
\text { Products } \\
\text { Manufact. } \\
\text { Full-time and } 1\end{array}$ & $\begin{array}{c}\text { Forest } \\
\text { Products } \\
\text { Manufact. } \\
\text { t-time Jobs }\end{array}$ & $\begin{array}{c}\text { Nature- } \\
\text { based } \\
\text { Recreation }\end{array}$ & $\begin{array}{c}\text { Food \& } \\
\text { Kindred } \\
\text { Products } \\
\text { Distribution }\end{array}$ & $\begin{array}{c}\text { Total All } \\
\text { Industries }\end{array}$ \\
\hline Gainesville & 14,842 & 5,717 & 1,186 & $\mathbf{3 , 5 7 7}$ & 1,705 & 303 & 25,783 & 53,112 \\
\hline Alachua & 3,055 & 3,959 & 771 & 474 & 778 & 26 & 18,160 & 27,223 \\
\hline Columbia & 1,895 & 302 & 144 & 435 & 197 & 31 & 3,089 & 6,093 \\
\hline Dixie & 617 & 57 & 4 & 1 & 340 & 1 & 335 & 1,356 \\
\hline Gilchrist & 895 & 206 & 8 & 202 & 29 & 22 & 345 & 1,706 \\
\hline Lafayette & 451 & 138 & 14 & 11 & 11 & 28 & 118 & 771 \\
\hline Jacksonville & 5,526 & 16,635 & 919 & 24,269 & 21,031 & 651 & $\mathbf{9 2 , 5 8 5}$ & 161,615 \\
\hline Baker & 352 & 88 & 0 & 0 & 22 & 0 & 779 & 1,241 \\
\hline Clay & 479 & 1,935 & 40 & 225 & 25 & 46 & 8,323 & 11,072 \\
\hline Duval & 1,160 & 11,286 & 317 & 23,810 & 9,487 & 215 & 64,275 & 110,550 \\
\hline Nassau & 1,032 & 661 & 0 & 43 & 5,802 & 59 & 3,672 & 11,269 \\
\hline Putnam & 1,194 & 572 & 86 & 14 & 5,168 & 86 & 2,244 & 9,364 \\
\hline St. Johns & 1,309 & 2,092 & 476 & 177 & 528 & 246 & 13,292 & 18,119 \\
\hline Miami-Fort Lauderdale & 76,869 & 84,654 & 16,943 & 37,142 & 8,675 & 3,654 & 413,071 & 641,007 \\
\hline Broward & 2,348 & 25,544 & 3,162 & 7,715 & 675 & 838 & 119,356 & 159,638 \\
\hline Okeechobee & 2,870 & 670 & 44 & 905 & 88 & 9 & 1,640 & 6,226 \\
\hline Palm Beach & 19,878 & 23,964 & 4,501 & 12,027 & 1,352 & 1,557 & 85,715 & 148,994 \\
\hline St. Lucie & 5,976 & 3,231 & 163 & 1,819 & 116 & 123 & 10,590 & 22,018 \\
\hline Orlando & 57,222 & 84,458 & 9,488 & 37,020 & 9,438 & 2,306 & 289,509 & 489,440 \\
\hline Brevard & 1,278 & 4,255 & 224 & 564 & 140 & 282 & 28,199 & 34,941 \\
\hline Citrus & 766 & 1,293 & 183 & 16 & 160 & 171 & 4,966 & 7,555 \\
\hline Flagler & 563 & 1,257 & 12 & 13 & 17 & 57 & 3,533 & 5,452 \\
\hline Hardee & 6,834 & 379 & 228 & 118 & 158 & 49 & 626 & 8,391 \\
\hline Highlands & 10,257 & 1,093 & 765 & 58 & 42 & 129 & 3,622 & 15,965 \\
\hline Lake & 4,405 & 6,096 & 1,613 & 3,523 & 182 & 91 & 12,899 & 28,809 \\
\hline Marion & 6,307 & 4,432 & 982 & 1,901 & 667 & 315 & 13,734 & 28,339 \\
\hline Orange & 4,327 & 22,045 & 400 & 8,414 & 1,231 & 371 & 118,865 & 155,653 \\
\hline Osceola & 1,385 & 2,977 & 375 & 469 & 124 & 121 & 16,784 & 22,235 \\
\hline
\end{tabular}




\begin{tabular}{|c|c|c|c|c|c|c|c|c|}
\hline \multirow[t]{2}{*}{ Region / County } & $\begin{array}{c}\text { Crop, } \\
\text { Livestock, } \\
\text { Forestry \& } \\
\text { Fisheries } \\
\text { Production }\end{array}$ & $\begin{array}{l}\text { Agricultural } \\
\text { Inputs \& } \\
\text { Services }\end{array}$ & Mining & $\begin{array}{c}\text { Food \& } \\
\text { Kindred } \\
\text { Products } \\
\text { Manufact. }\end{array}$ & $\begin{array}{c}\text { Forest } \\
\text { Products } \\
\text { Manufact. }\end{array}$ & $\begin{array}{c}\text { Nature- } \\
\text { based } \\
\text { Recreation }\end{array}$ & $\begin{array}{c}\text { Food \& } \\
\text { Kindred } \\
\text { Products } \\
\text { Distribution }\end{array}$ & $\begin{array}{c}\text { Total All } \\
\text { Industries }\end{array}$ \\
\hline & \multicolumn{8}{|c|}{ Full-time and Part-time Jobs } \\
\hline Polk & 15,910 & 24,615 & 3,019 & 19,780 & 4,156 & 212 & 25,545 & 93,237 \\
\hline Seminole & 662 & 9,438 & 115 & 678 & 2,291 & 108 & 27,327 & 40,619 \\
\hline Volusia & 3,610 & 5,900 & 786 & 1,101 & 97 & 210 & 28,489 & 40,194 \\
\hline Panama City & 5,095 & 2,395 & 2,638 & 498 & 4,451 & 299 & 18,725 & 34,103 \\
\hline Bay & 717 & 1,795 & 2,450 & 161 & 3,629 & 128 & 14,960 & 23,840 \\
\hline Calhoun & 648 & 73 & 18 & 1 & 87 & 66 & 397 & 1,291 \\
\hline Washington & 898 & 138 & 27 & 223 & 8 & 81 & 674 & 2,049 \\
\hline Pensacola & $\mathbf{3 , 8 2 7}$ & 5,608 & 4,498 & 912 & 3,938 & 390 & 45,786 & 64,959 \\
\hline Escambia & 1,163 & 655 & 1,317 & 338 & 3,851 & 252 & 18,455 & 26,031 \\
\hline Okaloosa & 1,015 & 2,298 & 2,483 & 40 & 2 & 103 & 15,857 & 21,798 \\
\hline Santa Rosa & 817 & 1,494 & 572 & 191 & 34 & 23 & 5,891 & 9,022 \\
\hline Walton & 831 & 1,162 & 127 & 344 & 50 & 12 & 5,583 & 8,108 \\
\hline Sarasota-Bradenton & 30,987 & 39,880 & 5,092 & 9,907 & 1,713 & 2,535 & 108,933 & 199,048 \\
\hline Charlotte & 1,517 & 2,675 & 1,164 & 17 & 9 & 147 & 7,757 & 13,286 \\
\hline Collier & 9,080 & 6,805 & 1,825 & 217 & 156 & 945 & 22,505 & 41,534 \\
\hline Franklin & 86 & 281 & 7 & 117 & 52 & 7 & 936 & 1,486 \\
\hline Gadsden & 1,757 & 301 & 450 & 56 & 485 & 23 & 1,111 & 4,182 \\
\hline Hamilton & 534 & 2,595 & 0 & 1 & 3 & 9 & 258 & 3,400 \\
\hline Jefferson & 931 & 149 & 5 & 8 & 18 & 6 & 372 & 1,489 \\
\hline Leon & 812 & 3,524 & 85 & 246 & 105 & 94 & 20,591 & 25,457 \\
\hline Liberty & 165 & 38 & 2 & 17 & 312 & 5 & 151 & 690 \\
\hline Madison & 1,448 & 84 & 0 & 531 & 133 & 82 & 497 & 2,774 \\
\hline Taylor & 980 & 142 & 114 & 153 & 5,327 & 4 & 710 & 7,430 \\
\hline Wakulla & 262 & 484 & 18 & 16 & 5 & 7 & 826 & 1,618 \\
\hline Tampa-St. Petersburg & 19,495 & 45,197 & 15,521 & 22,869 & 5,540 & 923 & 163,865 & 273,410 \\
\hline Hernando & 817 & 1,689 & 409 & 272 & 25 & 80 & 7,511 & 10,804 \\
\hline Hillsborough & 15,732 & 26,661 & 1,371 & 19,165 & 4,184 & 422 & 80,624 & 148,158 \\
\hline Pasco & 2,338 & 5,248 & 185 & 1,358 & 30 & 141 & 17,168 & 26,468 \\
\hline Pinellas & 608 & 11,600 & 13,555 & 2,075 & 1,301 & 280 & 58,562 & 87,981 \\
\hline Total All Regions & 220,839 & 292,142 & 56,966 & 137,339 & 62,929 & 11,296 & $1,183,709$ & $1,965,221$ \\
\hline
\end{tabular}

Impact estimates include regional multiplier effects.

Source: IMPLAN data for Florida (MIG, Inc.). 


\section{Share of Florida Gross Domestic Product and Employment}

The relative importance of agriculture, natural resources, and related food industries in Florida can be gauged by their share of overall economic activity in the state. The GDP of Florida in 2011, equivalent to the sum of direct value added for all industries, was $\$ 735.38$ billion, and total employment in the state was 9.747 million jobs. The direct value added of agriculture, natural resources, and related food industries in Florida was $\$ 62.63$ billion in 2011, which represented 8.5 percent of the GDP (Figure 10), while the total value-added impact, including regional multiplier effects, was $\$ 104.30$ billion, representing 14.2 percent of state GDP. Direct employment by agriculture, natural resources and related food industries was 1.41 million full-time and part-time jobs, representing 14.4 percent of all jobs in the state in 2011 (Figure 11), while total employment impacts of 1.97 million full-time and part-time jobs represented 20.2 percent of all jobs in the state. Excluding the Food and Kindred Products Distribution industry group, agriculture, natural resources and related food industries represented 6.52 percent of total contributions to GDP and 8.02 percent of total state employment.

The share of total employment and value-added contributions by agriculture, natural resources, and related food industries in each Florida County is mapped in Figures 12 and 13, respectively, with greater relative contributions indicated by darker shading. 
Figure 10. Direct value-added by major industry groups as a share of Florida GDP in 2011

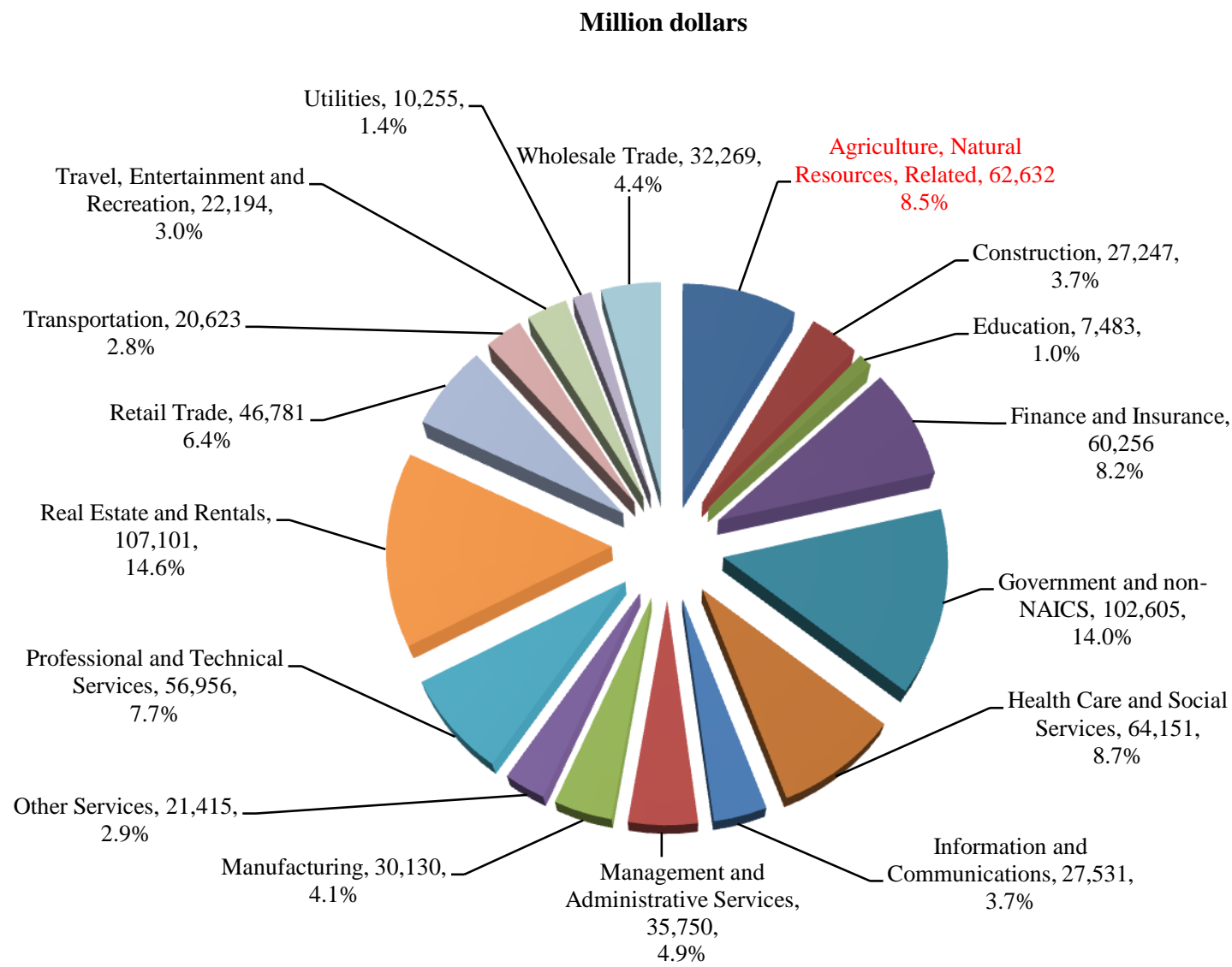

Source: IMPLAN data for Florida (MIG, Inc.). 
Figure 11. Direct employment by major industry groups in Florida in 2011

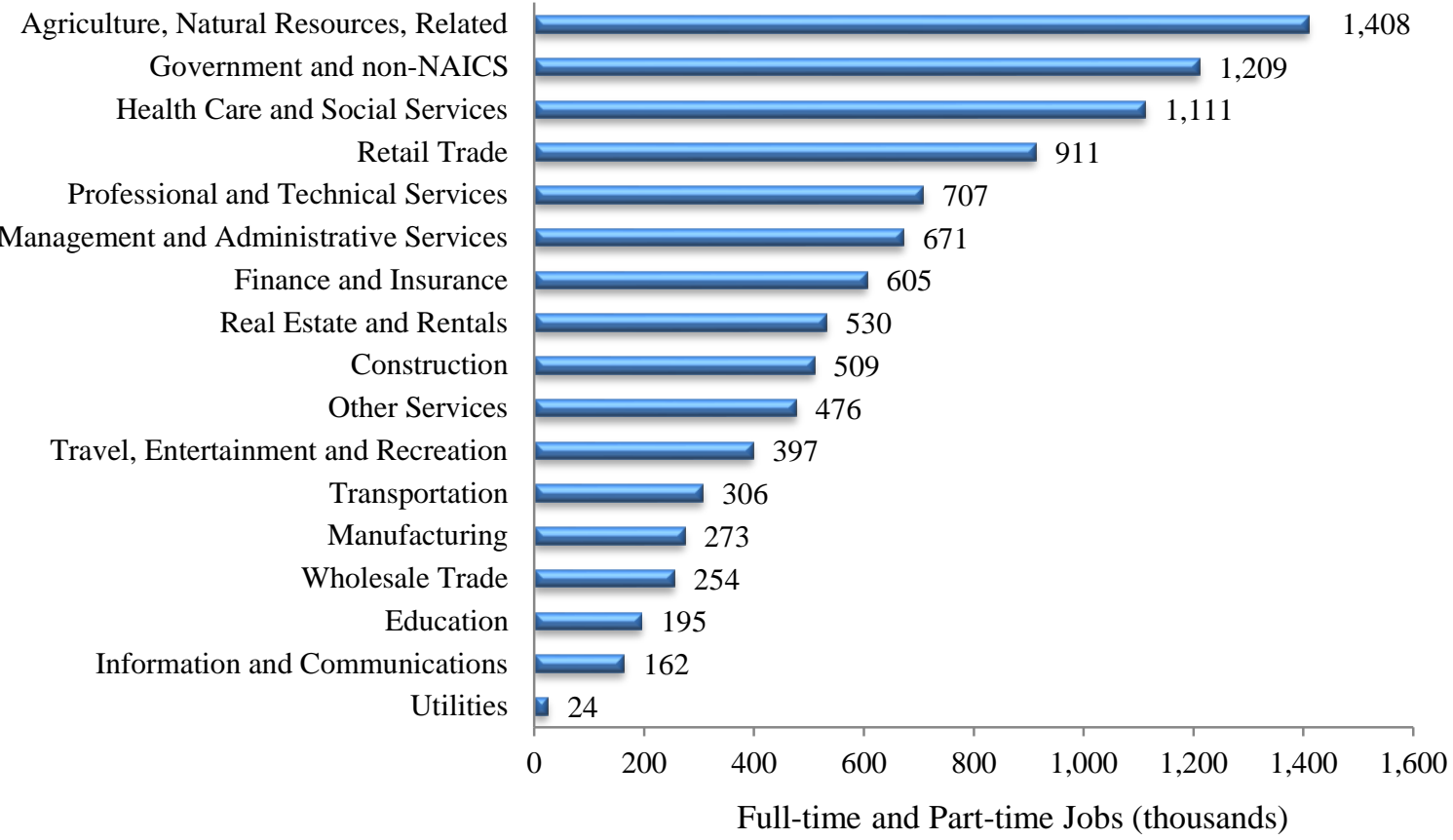

Source: IMPLAN data for Florida (MIG, Inc.).

Figure 12. Map of share of total employment contributions by agriculture, natural resources, and related food industries in Florida counties in 2011

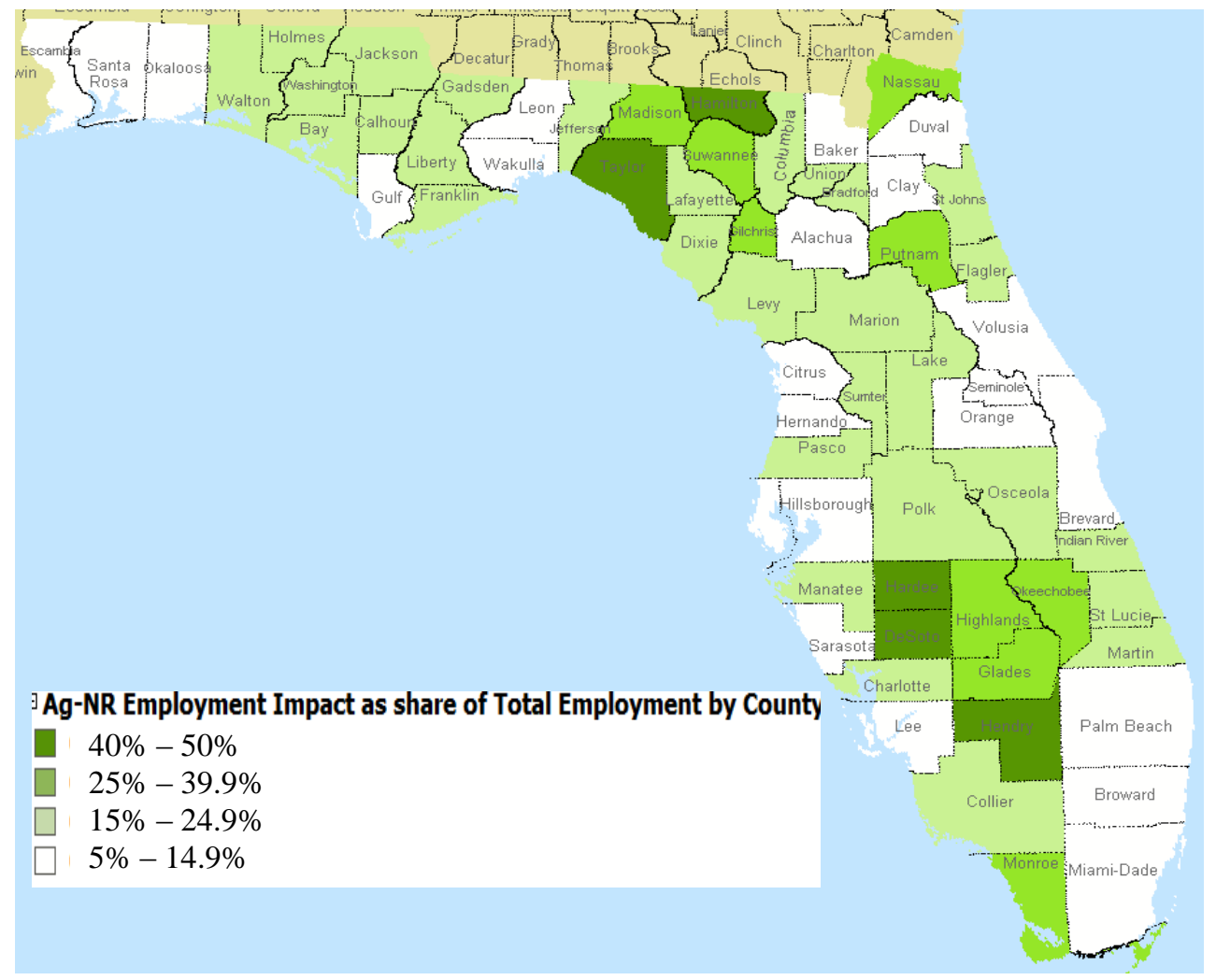


Figure 13. Map of share of contributions to GDP by agriculture, natural resources, and related food industries in Florida counties in 2011

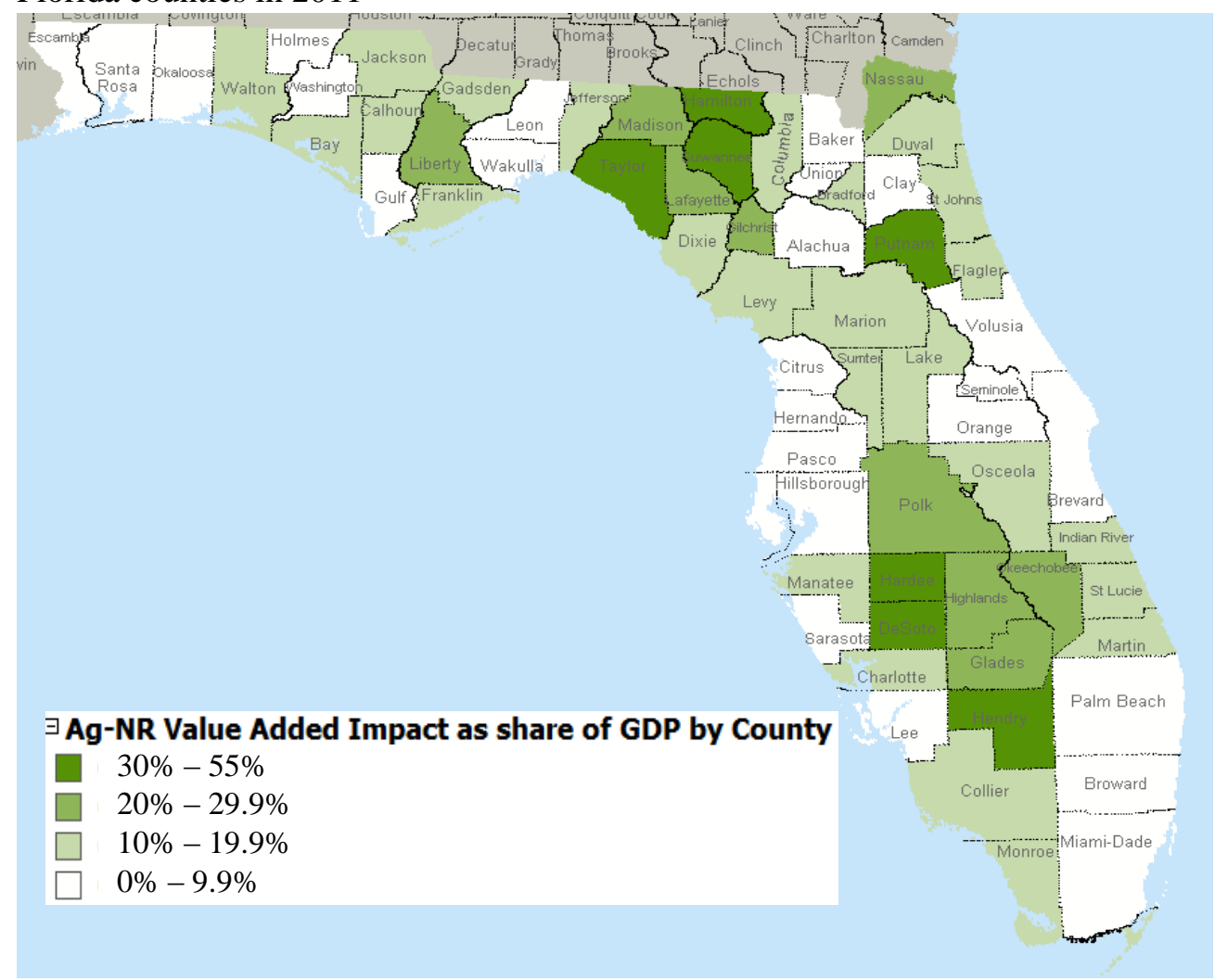

Source: IMPLAN data for Florida (MIG, Inc.).

\section{Trends in Economic Contributions over Time}

In addition to the status of economic contributions made by agriculture, natural resources, and related food industries to the state in 2011, it is important to understand how these values have changed over time. Trends in the economic contributions between 2001 and 2011 are shown in Figures 14 to 18, with all monetary values adjusted for inflation and expressed in constant 2011 U.S. dollars. Note that these trends may reflect changes in commodity prices, the structure of Florida's economy, and the business cycle of the national and global economy. Direct employment in Florida's agriculture, natural resources and related food industries grew from 1.28 million jobs in 2001 to 1.40 million jobs in 2008, then declined to 1.33 million jobs in 2009, as a result of the global recession, but recovered to 1.41 million in 2011. Annual job growth in agriculture and related industries averaged 0.8 percent over the 11 -year period. Total employment impacts increased to 1.97 million jobs in 2011 , reflecting an increase in exports to domestic and world markets, and representing a 1.2 percent average annual growth during 2001-2011 based on the linear regression trend (Figure 14). 
Total value-added impacts grew from $\$ 82.29$ billion in 2001 to $\$ 104.30$ billion in 2011 , representing a 2.5 percent average annual growth rate in inflation-adjusted terms (Figure 15). Among industry groups, average annual growth in value-added impacts during 2001-2011 was highest for Mining (8.3\%), followed by Agricultural Inputs and Services (5.4\%) and Food and Kindred Products Distribution (4.1\%), while groups with negative growth during this period included Forest Products Manufacturing (-0.3\%); Crop, Livestock, Fisheries, and Forestry Production (-0.3\%); Food and Kindred Product Manufacturing (-0.9\%); and Nature-based recreation (-15.2\%).

Trends in employment and value-added impacts among Florida's food and fiber commodity groups between 2001 and 2011 are shown in Figures 16 to 17. The Environmental Horticulture commodity group showed the highest increase in employment impacts (49\%), followed by Fruit and Vegetable Farming and Processing (7\%). Commodity groups that suffered a decline in employment impacts included Livestock Farming and Animal Products Manufacturing (-41\%); Grain and Oilseed Farming and Processing (-40\%); Fishing and Seafood Products (-26\%); and Sugarcane Farming and Refined Sugar and Confections (-16\%) (Figure16). The Environmental Horticulture commodity group also had the highest growth in value-added impacts (38\%), followed by Agricultural Inputs and Services (16\%); Grain and Oilseed Farming and Processing (16\%); and Fruit and Vegetable Farming and Processing (9\%) (Figure 17). The Fishing and Seafood Products commodity group suffered the greatest decline in value-added impacts (-42\%), followed by Sugarcane Farming and Refined Sugar and Confections (-40\%) and Livestock Farming and Animal Products Manufacturing (-24\%).

Individual industry sectors with average yearly growth rates in value-added impacts greater than 20 percent during 2001-2011 included Soybean and other oilseed processing (29\%); Wet corn milling (29\%); Tortilla manufacturing (27\%); Breakfast cereal manufacturing (27\%); Tree nut farming (24\%); and Extraction of oil and natural gas $(20 \%)$.

Across all industry groups in Florida, Agriculture, Natural Resources, and Related Food Industries was among the major sectors that experienced positive growth in direct value-added contributions during 2001-2011. Among seventeen major industry groups, those with the highest average annual growth in direct value added were Education (6.0\%); Government (3.8\%); Health Care and Social Services (3.4\%); Professional and Technical Services (3.1\%); Travel, Entertainment, and Recreation (3.0\%); Real Estate and Rentals (2.6\%); Finance and Insurance (2.5\%); and Agriculture, Natural Resources, and Related Industries (1.8\%). 
Figure 14. Trend in employment contributions by agriculture, natural resources, and related food industries in Florida, 2001 to 2011

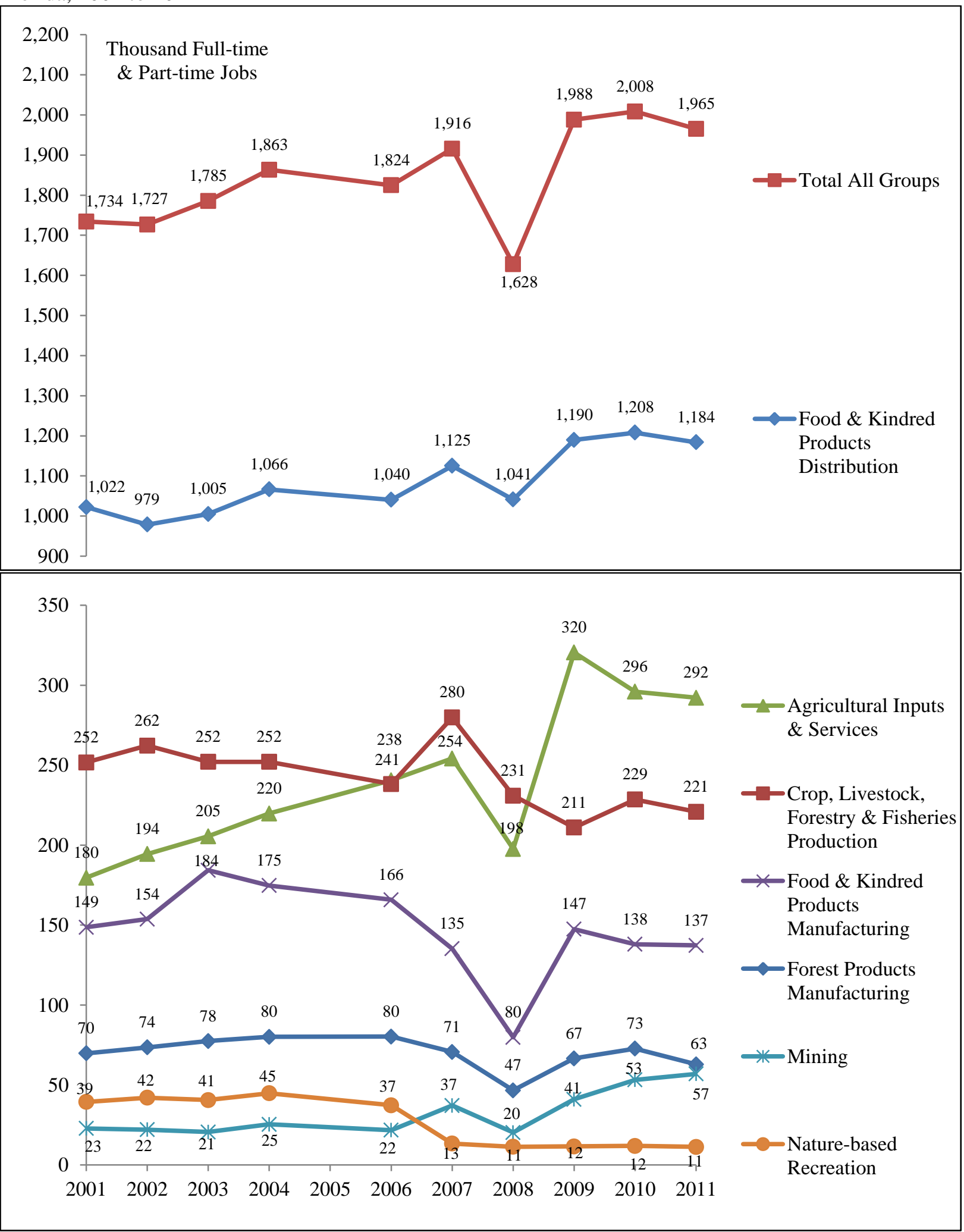

Data not available for 2005. Estimates include regional multiplier effects.

Source: IMPLAN data for Florida (MIG, Inc.). 
Figure 15. Trend in value-added contributions by agriculture, natural resources, and related food industries in Florida, 2001 to 2011
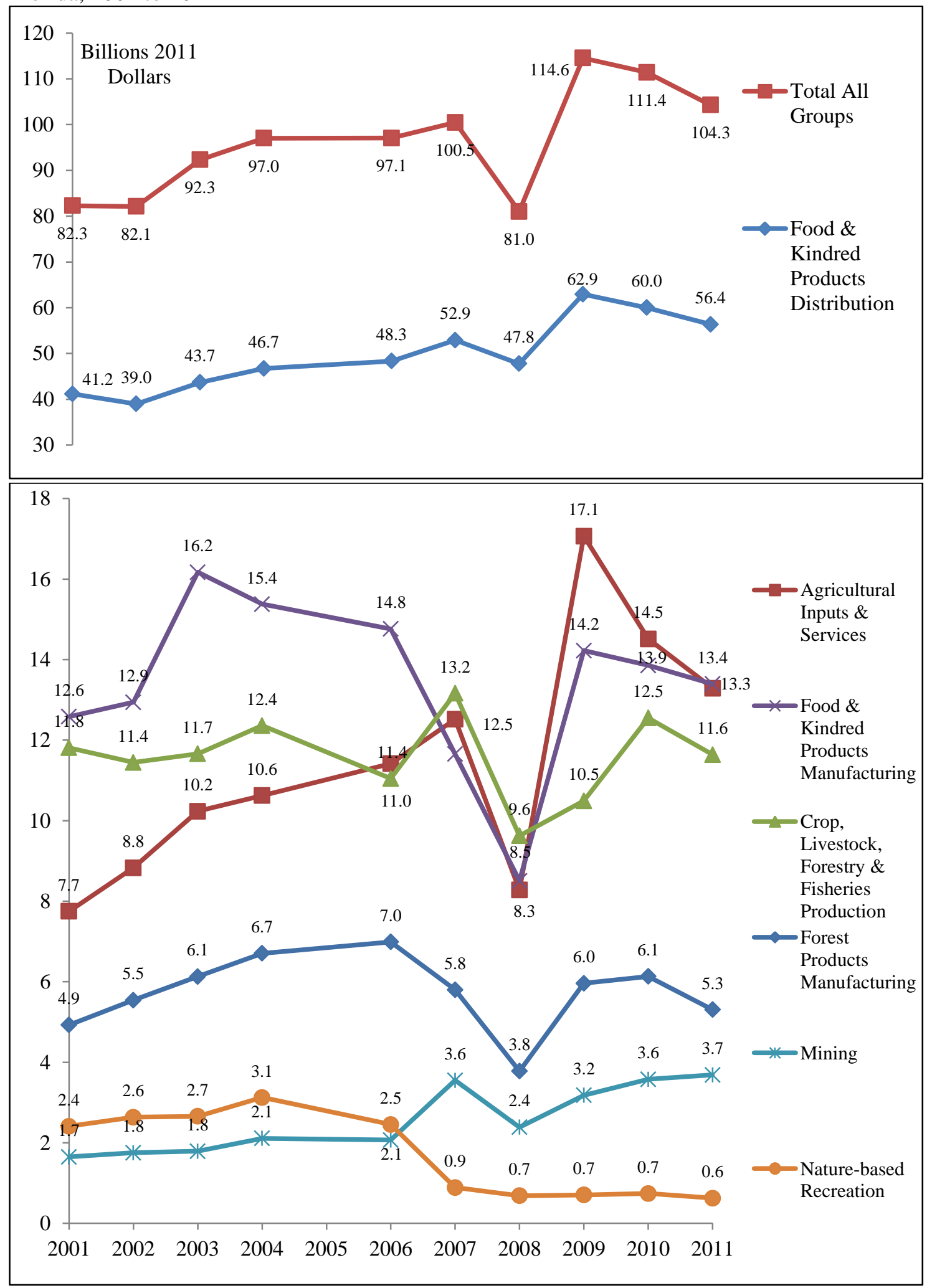

Data not available for 2005. Values expressed in 2011 dollars. Estimates include regional multiplier effects. Source: IMPLAN data for Florida (MIG, Inc). 
Figure 16. Trend in employment contributions by food and fiber commodity groups in Florida, 2001 to 2011

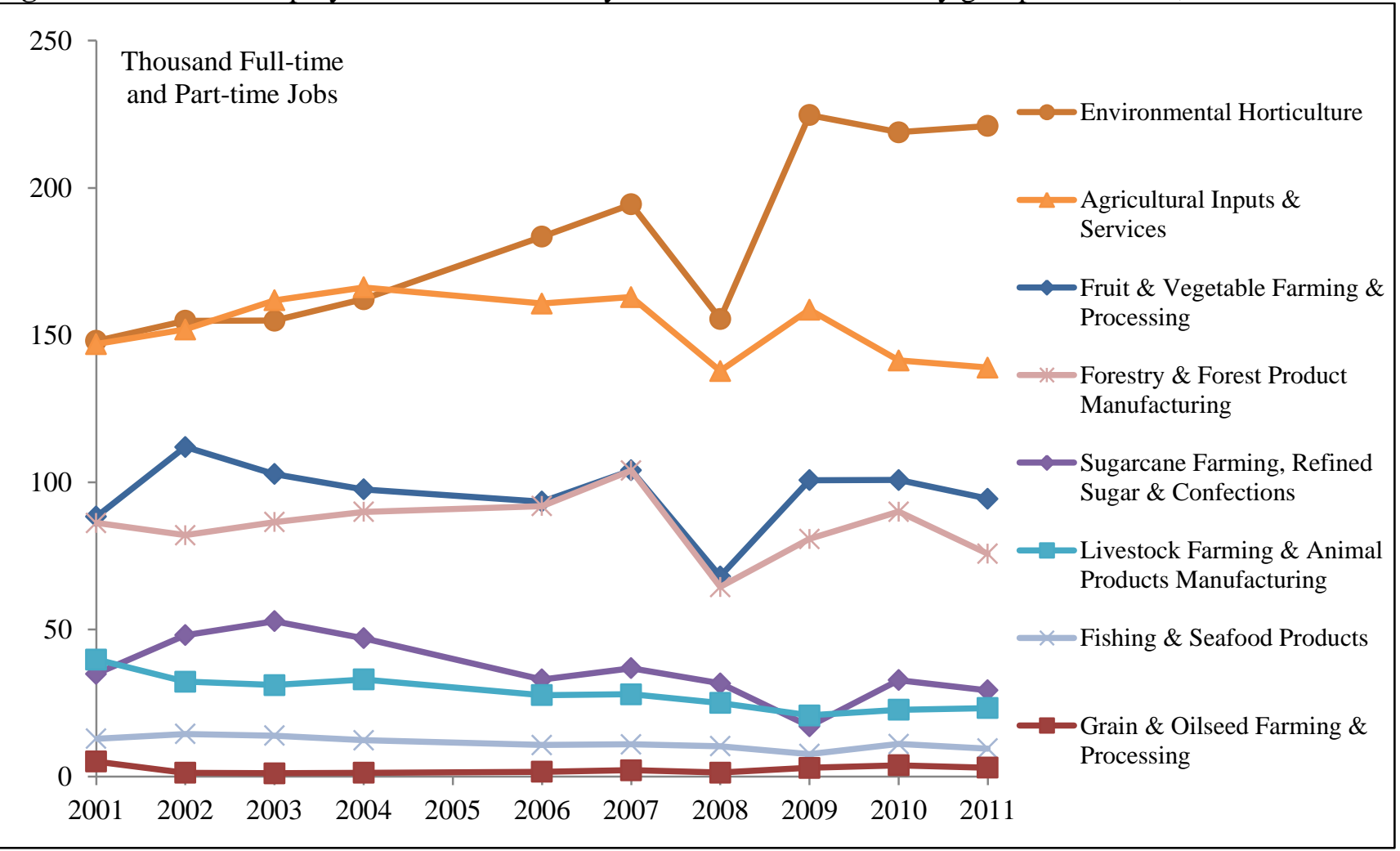

Data not available for 2005. Estimates include regional multiplier effects.

Source: IMPLAN data for Florida (MIG, Inc.). 
Figure 17. Trend in value-added contributions by food and fiber commodity groups in Florida, 2001 to 2011

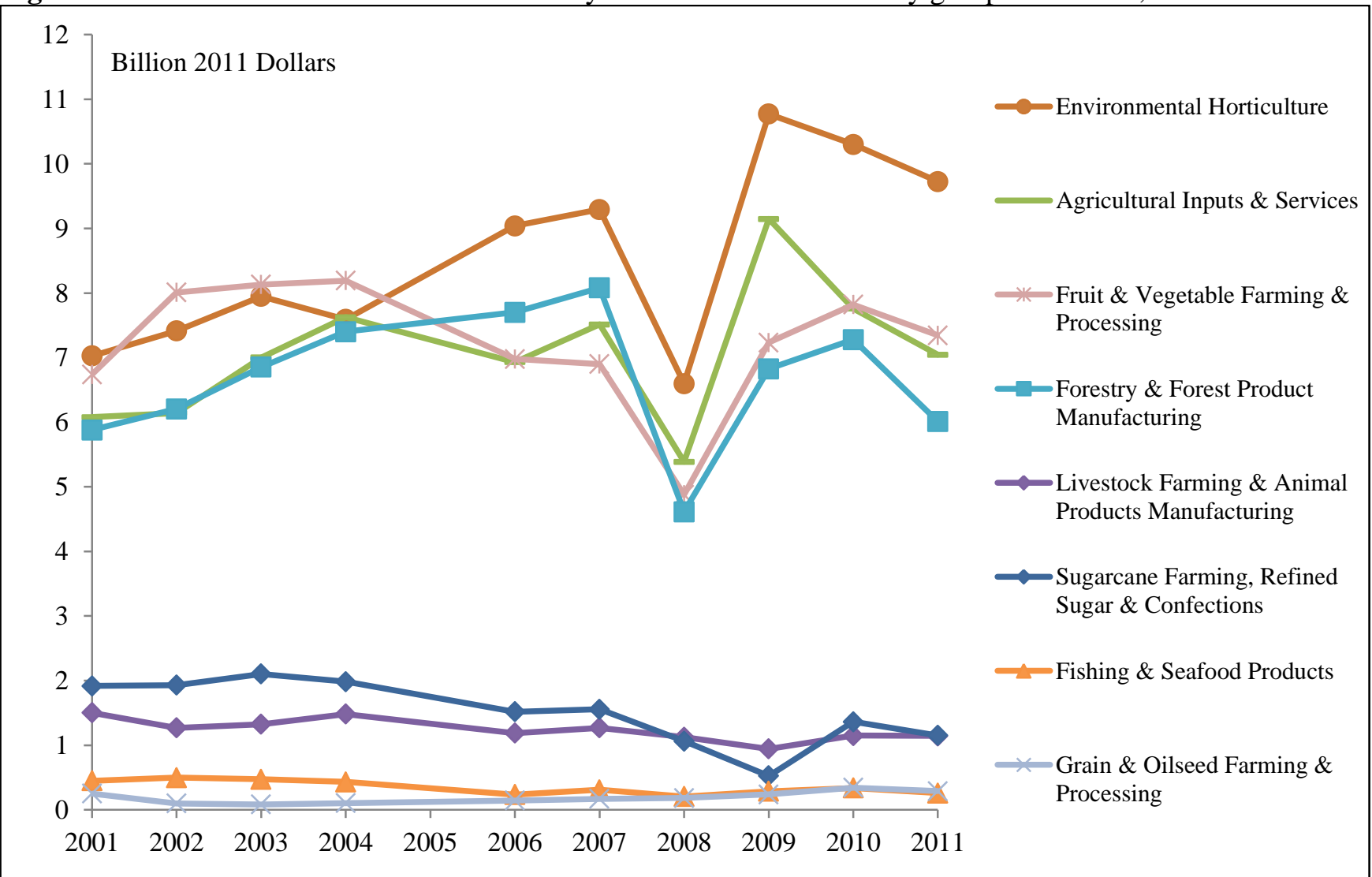

Data not available for 2005. Estimates include regional multiplier effects. Source: IMPLAN data for Florida (MIG, Inc.). 
Figure 18. Trend in exports by food and fiber commodity groups in Florida, 2001 to 2011

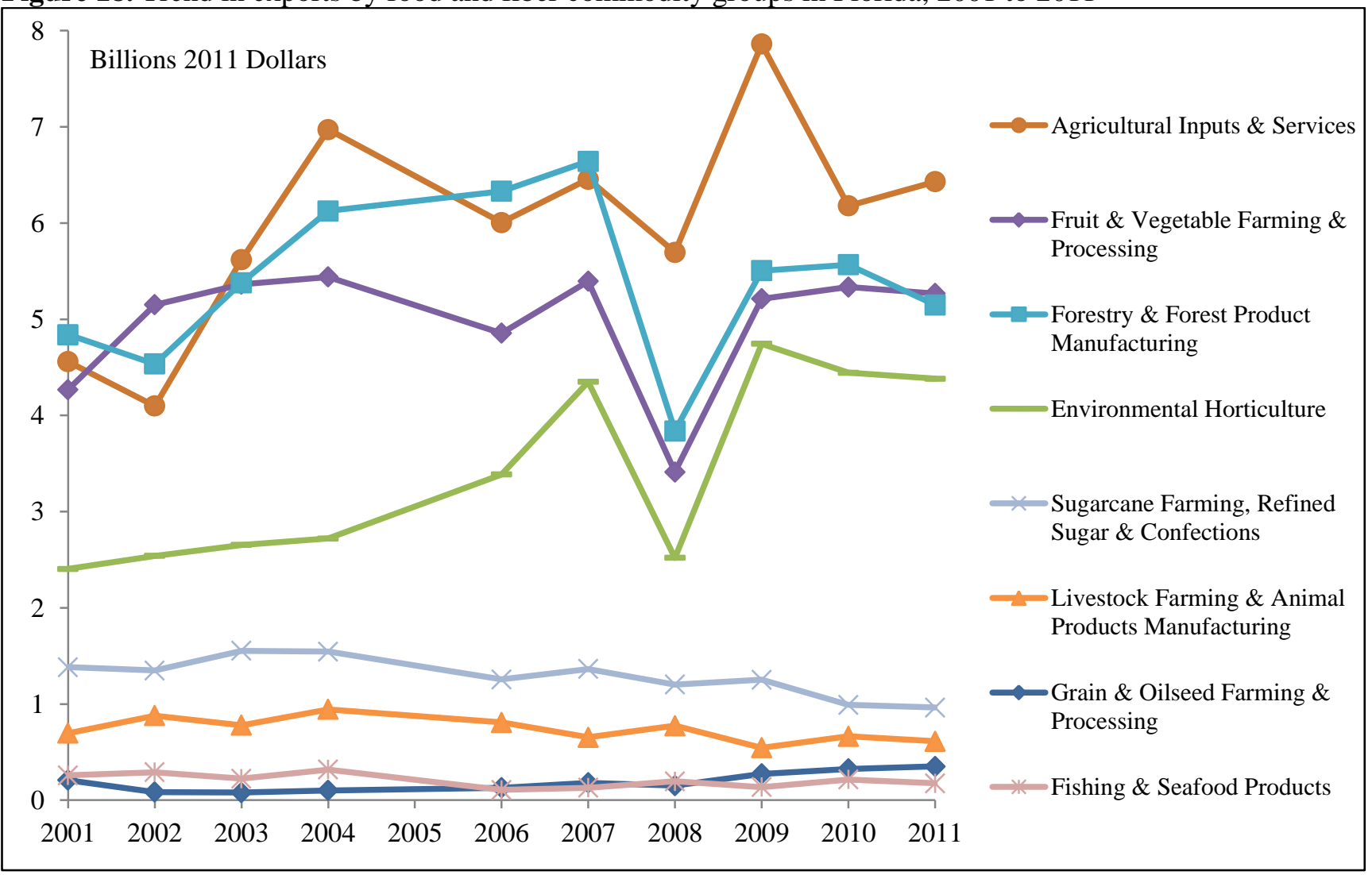

Note data not available for 2005. Estimates include regional multiplier effects.

Source: IMPLAN data for Florida (MIG, Inc.).

\section{Conclusions}

Agriculture and natural resource industries in Florida are linked to a broad array of economic sectors for commodity production, food and kindred product manufacturing, distribution, and related service activities. These industries collectively had a significant economic impact on Florida's economy in 2011, with direct employment accounting for about 14.4 percent of total state employment and direct value added representing 8.5 percent of state GDP. Food and Kindred Products Distribution was by far the largest segment of the industry group, representing 54 percent of value added and 60 percent of employment impacts. These industries are present throughout the state, with major activity in urbanized metropolitan areas, but are relatively more important as a share of total economic activity in rural counties. The agriculture, natural resources, and related industries have grown substantially since 2001, interrupted in 2008 by the global recession, but continuing recovery in 2011, with total regional economic impacts increased dramatically due to increased exports. Growth in economic activity of agriculture, natural resources, and related food industries during the past ten years was higher than many other major industry groups, thus contributing towards the stability and sustainability of the Florida economy. 


\section{Literature and Information Sources Cited}

Hodges, A.W., M. Rahmani, and Thomas Stevens. 2012. Economic contributions of agricultural, natural resource, and related industries in Florida for 2010. Electronic Data Information Source (EDIS) FE906. University of Florida, Gainesville, FL. http://edis.ifas.ufl.edu/FE906.

Hodges, A.W., M. Rahmani and Thomas Stevens. 2011. Economic contributions of Florida's agricultural, natural resource, food and kindred product manufacturing and distribution, and service industries in 2009. Electronic Data Information Source (EDIS) FE829. University of Florida, Gainesville, FL. http://edis.ifas.ufl.edu/FE897.

Hodges, A.W. and M. Rahmani. 2010. Economic contributions of Florida's agricultural, natural resource, food and kindred product manufacturing and distribution, and service industries in 2008. Electronic Data Information Source (EDIS) FE829. University of Florida, Gainesville, FL. http://edis.ifas.ufl.edu/FE829.

Hodges, A.W. and M. Rahmani, 2009. Economic contributions of Florida's agricultural, natural resource, food and kindred product manufacturing and distribution, and service industries in 2007. Electronic Data Information Source (EDIS) FE800. University of Florida, Gainesville, FL. http://edis.ifas.ufl.edu/FE800.

Hodges, A.W., M. Rahmani, and W.D. Mulkey, 2008. Economic contributions of agricultural, food manufacturing, and natural resource industries in Florida in 2006. Electronic Data Information Source (EDIS) FE702. University of Florida, Gainesville, FL. http://edis.ifas.ufl.edu/FE702.

Johnson, K. and J. Kort. 2004. Redefinition of the BEA economic areas. Survey of Current Business. United States Department of Commerce, Bureau of Economic Analysis, Washington, D.C. (November). http://www.bea.gov/scb/pdf/2004/11November/1104Econ-Areas.pdf.

Minnesota IMPLAN Group, Inc. (MIG). IMPLAN Professional software for impact analysis and social accounting (version 3.0) and Florida state and county data for 2001-09. Stillwater, MN. http://www.implan.com.

Miller, R.E. and P.D. Blair. 2009. Input-Output Analysis: Foundations and Extensions, Second Edition. Cambridge, UK: Cambridge University Press.

United States Department of Commerce, Bureau of Economic Analysis (USDOC/BEA). Various Years. Gross Domestic Product Implicit Price Deflator, 1970-2010 (quarterly), USDOC/BEA, Washington, D.C. http://research.stlouisfed.org/fred/data/gdp/gdpdef.

Watson, P., J. Wilson, D. Thilmany, and S. Winter. 2007. Determining economic contributions and impacts: what is the difference and why do we care? Journal of Regional Analysis and Policy 37(2):140-146. http://www.jrap-journal.org/pastvolumes/2000/v37/F37-2-6.pdf. 